\title{
Bulanık AHP ve Bulanık Gri İlişkisel Analiz Yöntemleri ile Kargo Uçak Tipi Seçimi: Bir Türk Havayolu Firmasında Uygulama
}

\author{
Fuzzy AHP and Fuzzy Grey Relational Method for Cargo Aircraft Type \\ Selection: A Case Study in a Turkish Airline Company
}

\author{
İbrahim Zeki AKYURT, İstanbul Üniversitesi, Türkiye, zekiakyurt@gmail.com \\ Orcid No: 0000-0003-4817-5267 \\ Nihan KABADAYI, İstanbul Üniversitesi, Türkiye, nihank@istanbul.edu.tr \\ Orcid No: 0000-0003-1950-4877
}

\begin{abstract}
Öz: Küreselleşme ve teknolojik gelişmeler pazar koşullarını birçok yönden etkilemiştir. Bu gelişmeler ile birlikte ülkeler arasındaki ticari sınırlar ortadan kalkmış ve firmalar için ucuz işçilik, hammadde kaynaklarına ve yeni pazarlar ulaş̧labilirlik artmıştır. Öte yandan, kisalan ürün hayat eğrileri, teslimat süreleri ve kişiselleşmiş ürünlere olan talebin artması küreselleşmenin bazı zorlayıcı sonuçları olmuş̧tur. Firmalar değişen pazar koşullarını karşılayabilmek ve zorlayıcı rekabet koşullarında stratejik bașarılar elde edebilmek için farklı tașıma modlarını etkin bir şekilde kullanmalıdır. Bunun sonucu olarak hızlı ve güvenilir teslimat sağlayan havayolu taşımacılığı günümüzde operasyonel süreçlerde popüler hale gelmiştir. Havacıllkta artan talep hacmine bağlı olarak, Türk hava kargo sektörü son yıllarda hızla büyümektedir. Bu durum, bölgede hizmet veren hava taşımacıllğl şirketlerini, artan talebi karşılamak için filoların genişletmeye yönelmişsir. Kargo uçağı seçimi havayolu firmaları için stratejik bir karar olmakla beraber çoklu çelişen kriterlerin aynı anda dikkate alınacă̆ çok kriterli bir karar verme problemidir. Bu çalışmanın amacı havayolu kargo uçağl seçim süreci için belirlenen kritik kriterleri bulanık analitik hiyerarşi prosesi (AHP) yöntemini kullanarak önemlerine göre siralamak ve bulanık gri ilişkisel analiz yöntemi (GIA) ile kargo uçağı seçimi problem için alternatif bir çözüm önerisinde bulunmaktır. Ayrica yöntem bir Türk hava kargo şirketinde uygulanarak yöntemin performansı ölçümlenmiştir.
\end{abstract}

Anahtar Sözcükler: Kargo Uçağı, Havayolu Kargo, Çok kriterli karar verme, Bulanık AHP, Bulanık Gri İlişkisel Analiz JEL Sinıflandırması: M110; L930; R410; C600

\begin{abstract}
Globalization and technological developments have affected market conditions in many ways. These developments removed the economic boundaries among countries and gave great opportunities to companies, such as access to cheap labor, raw material and new markets. On the other hand, short product life cycles, delivery times and customization are some of the challenging results of globalization. To meet that challenging market requirements and achieve a competitive advantage, firms ought to operate and use all their transportation modes effectively. Consequently, airline transportation has become more popular in operations since it provides quick and reliable delivery. Due to increasing demand volume in aviation, Turkish air cargo industry has been growing rapidly in last decades. Therefore, airfreight companies are looking to expand their fleet to capitalize on growing in the region. Selecting the most suitable cargo aircraft has a critical importance in terms of the competitiveness. Cargo aircraft selection is a multi-criteria decision-making problem in which multiple conflicting criteria are to be considered simultaneously. The aim of this study is to determine critical criteria set for air cargo plane selection process and rank them according to their importance with using a fuzzy analytical hierarchy process $(A H P)$ method and select the most suitable cargo aircraft using fuzzy grey relational analysis (GIA) method. A real life case study is conducted at a Turkish air cargo company to test the performance of the proposed method.
\end{abstract}

Keywords: Freighter, Air Cargo, Multi Criteria Decision Making, Fuzzy AHP, Fuzzy Grey Relational Analysis JEL Classification: M110; L930; R410; C600

\section{Giriș}

Taşımacılık faaliyetleri, ürünün değer kazanacağı yere ulaştırılması fonksiyonunu üstlenmesiyle tedarik zincirinde önemli bir role sahiptir. Hammadde, malzeme ve bitmiş ürünlerin, tedarik zinciri içindeki dolaşımı ve nihai müşteriye teslimi taşımacılık faaliyetleriyle sağlanmaktadır. Taşımacılık faaliyetleri, malzemelerin coğrafi olarak yer değiştirilmesi ve konumlandırılmasını sağlayarak tedarik zincirinin halkalarını, birbirine fiziksel olarak bağlar. Taşıma, tedarik zincirinde zaman ve yer faydasının elde edilmesini kolaylaştırır. Günümüzde artan küreselleşme ile birlikte firmalar maliyet veya gelir avantajı elde edebilmek amacıyla dünyanın farklı coğrafyalarında faaliyet göstermektedir. Bunun sonucu olarak tedarik zincirlerinin kapsadığı coğrafi alanlar genişlemekte ve taşıma süreleri uzamaktadır. Ancak kısa ürün hayat eğrisine sahip olan ürünler ve teslimat sürelerinin müşteri memnuniyeti üzerindeki etkisi nedeniyle firmalar taşıma sürelerini minimize etmeyi hedeflemektedir. Bu nedenle en büyük avantajı "süratli teslimat" olan havayolu kargo taşımacılığı, ticarette önem kazanmıştır.

Uluslararası ve ulusal havayolu kargo taşımacılığı özellikli bir taşımacılık türü olup uzun mesafeler arasında küçük hacimli ve kıymetli kargoların taşınmasında sıklıkla kullanılmaktadır. Günümüz modern kargo uçakları saatte 500-600 mil hızla taşımacılık yapabilmektedir. Böylece uzak mesafelere yük taşımacılığında zaman faydası sağlamaktadır. Havayolu kargo taşımacılığı, yurtiçi taşımalarda, karayolu ile yurtdışı taşımalarda ise demir ve deniz yolu ile rekabet

Makale Gecmiși / Article History

Başvuru Tarihi / Date of Application Kabul Tarihi / Acceptance Date
: 22 Ağustos / August 2019

: 30 Ekim / October 2019 
etmektedir. Havayolu kargo taşımacılığı, küresel ticaret hacminin miktar olarak sadece \%1'ini, değer olarak ise \%35'ini oluşturmaktadır (IATA, 2018). Uluslararası posta konvansiyonuna göre, posta veya doküman ile kayıtlı bagaj haricinde, gümrüğe tabi ve konşimento kayıtlı olarak uçakla taşınan her türlü gönderi hava kargo sınıfında yer almaktadır. Kargo uçağı ise yolcu uçağı dışında sadece kargo taşıyan uçak tiplerinin genel ismidir. Hava kargo taşımacılığında, özel kargolar, transfer kargolar, ağır kargolar (Heavy Cargo), tehlikeli maddeler (Dangerous Goods), değerli kargo (Valuable Cargo), cenaze (HUM), canlı hayvan (AVI), bozulabilir kargolar (PER), yiyecek malzemeleri (EAT), canlı bitki ve bitki türleri taşınabilmektedir. Günümüzde yolcu uçakları da kargo taşımacılığı yapmaktadır. Bu nedenle son yıllarda geniş gövdeli yolcu uçakları, yüksek kargo taşıma kapasitesine uygun üretilmektedir.

Günümüzde havayolu kargo taşımacılığı raf ömrü kısa olan ürünlerin taşınmasında kritik bir öneme sahiptir. Bu türdeki ürünlerin dünyanın bir ucundan diğer ucuna kısa sürede taşınması sadece havayolu kargo ile mümkün olabilmektedir. Bozulabilir ürünler, tüketici elektroniği, lüks hazır giyim, ilaç, endüstriyel makine ve otomobil parçaları gibi zamana duyarlı ve yüksek değerli ürünlerin taşınmasını gerektiren endüstriler nakliye kararlarında hava taşımacılığını tercih etmektedirler. Ayrıca ilaç endüstrisinde yüksek değerli, zaman ve sıcaklık hassas ürünlerin aşınmasında hız ve verimlilik açısından avantaj sağlamaktadır. Canlı hayvan taşımacılığında uzak mesafeler için havayolu kargo taşımacılığının en insani ve uygun taşıma yolu olduğu düşünülmektedir. Ürün yaşam eğrisi kısa olan elektronik ürünlerin küresel tedarik zincirlerinde havayolu kargo taşımacılığı stratejik bir önem taşımaktadır. E-ticaret firmalarının hızlı teslimat süreleriyle rekabetinde havayolu kargo taşımacılığı firmalara bu konuda önemli avantajlar sağlamaktadır (IATA, 2018). Yapılan araştırmalara göre, son 15 yılda Dünya'daki GSMH' nın artışıyla birlikte pahalı ürünlere olan talep de artmıştır. Bu durum, gelecek yıllarda zaman duyarlılığı yüksek ve ekonomik olarak kısa raf ömrüne sahip ürünlerin taşımacılığında havayolu kargo taşımacılığının tercih sebebi olacağının tahmin edilmesine neden olmaktadır (Boeing, 2017).

Dünyada Ticari Havacılık, II. Dünya Savaşı'ndan sonra gelişmeye başlamıştır. Son yıllarda 2012 yılında yaşanmış olan \%1,2 oranındaki gerilemeden sonra birbirini takip eden yıllar boyunca pozitif yönde bir ilerleme kaydetmiştir. 2014 yılında \%4,8 oranında büyümüş, 2015 yılında büyüme hızı biraz yavaşlasa da pazarda \%1,9 oranında bir büyüme gerçekleşmiştir. 2017 yılı büyüme oranı ise \%10,1 olarak gerçekleşmiştir. Yapılan araştırmalara göre 2018 yılında da uzun dönemli olarak bu büyümenin devam edeceği tahmin edilmektedir. Önümüzdeki 20 yıl boyunca dünya havayolu kargo trafiğinin yılda ortalama \% 4,2 oranında büyümeye devam edeceği ve tahmin periyodunun sonunda havayolu kargo uçağı filo sayısının \%70 oranında artacağı ön görülmektedir (Boeing, 2018). Tablo 1'de Boeing firması tarafından yapılmış olan araştırmanın sonuçlarına göre geçmiş yıllara ait gerçekleşen ve gelecek 20 yıl için tahmin edilen ortalama yüzdesel büyüme oranları yer almaktadır.

Tablo 1. Geçmiş ve Gelecek Dönem Havayolu Kargo Büyüme Oranları

\begin{tabular}{|l|c|c|}
\hline Bölge & $\begin{array}{c}\text { Geçmiş } \\
\text { Gerçekleşen Büyüme oranlarl(\%) }\end{array}$ & $\begin{array}{c}\text { Gelecek Dönem (2015-2035) Tahmin } \\
\text { Edilen Büyüme oranlart (\%) }\end{array}$ \\
\hline Dünya & 2,6 & 4,2 \\
\hline Doğu Asya-Kuzey Amerika & 1,2 & 4,7 \\
\hline Avrupa- Doğu Asya & 4,2 & 4,7 \\
\hline Asya-Asya & 3,8 & 5,8 \\
\hline Avrupa-Kuzey Amerika & 0 & 2,5 \\
\hline Kuzey Amerika-Kuzey Amerika & 2,3 & 2,3 \\
\hline Çin & 5 & 6,3 \\
\hline Latin Amerika-Avrupa & 3,0 & 4,0 \\
\hline Latin Amerika-Kuzey Amerika & $-0,3$ & 4,1 \\
\hline Afrika-Avrupa & $-1,0$ & 3,7 \\
\hline Güney Asya-Avrupa & 2,4 & 4,2 \\
\hline Orta Dŏ̆u-Avrupa & 3,3 & 3,2 \\
\hline Avrupa-Avrupa & 3,1 & 2,3 \\
\hline
\end{tabular}

Türkiye, Avrupa'da en hızlı gelişim gösteren ülkelerden biridir. Türk havayolu işletmeleri özellikle uluslararası uçuş noktalarını her geçen gün arttırarak yoğun rekabet koşulları içerisinde bulunan dünya pazarında başarılı bir şekilde faaliyet göstermektedir. Türkiye'nin coğrafi özellikleri de dikkate alındığında gelişmekte olan bu sektördeki başarısını sürdürülebilir kılması büyük önem taşımaktadır. Özellikle İstanbul merkezli faaliyetleriyle, Asya ve Ortadoğu'ya ve Avrupa'ya çok hızlı sürelerde taşımacılık imkânı sağlamaktadır. Bu bağlamda Türkiye bir merkez konumundadır. Ayrıca Türkiye hava taşımacılığında yolcu sayısı olarak Avrupa'da 4. Dünyada ise 9. Sıradadır. Bunun yanı sıra Türkiye'de hava taşımacılığı son 12 yılda ortalama \%15 büyümüştür. Tablo 2'de de görüleceği üzere, hava kargo taşımacılığı ise son 15 
yılda ortalama \%11 büyümüştür. Türkiye havalimanlarından hava kargo taşımacılığının en yoğun olarak gerçekleştiği kıta Avrupa olmuştur. Avrupa'yı sırasıyla Asya, Ortadoğu, Kuzey Amerika, Afrika, Güney Amerika ve Rusya izlemektedir. Ülkeler bazında bakılacak olursa, Avrupa'da en çok Almanya, Asya'da en çok Çin, Ortadoğu'da Birleşik Arap Emirlikleri, Kuzey Amerika'da ABD, Afrika'da Nijerya, Güney Amerika'da Brezilya hava kargo taşımacılığının en yoğun olduğu ülkeler olmuştur. (https://www.utikad.org.tr/Detay/Sektor-Haberleri/13644/hava-kargo-tasimalari-10yilda-3-kat-artti)

Tablo 2. Türkiye Kargo Trafiği (TON)

\begin{tabular}{|c|c|c|c|}
\hline$Y I L$ & $\begin{array}{l}\dot{I c ̧} H a t \\
\text { (Ton) }\end{array}$ & $\begin{array}{l}\text { Dlş Hat } \\
\text { (Ton) }\end{array}$ & $\begin{array}{l}\text { Genel Toplam } \\
\text { (Ton) }\end{array}$ \\
\hline 2003 & $54.107,30$ & $222.177,50$ & $276.284,80$ \\
\hline 2004 & $71.000,80$ & $253.590,60$ & $324.591,40$ \\
\hline 2005 & $72.204,10$ & $258.910,90$ & $331.115,00$ \\
\hline 2006 & $70.323,50$ & $278.404,80$ & $348.728,30$ \\
\hline 2007 & $72.439,60$ & $312.588,90$ & $385.028,50$ \\
\hline 2008 & $66.110,60$ & $328.898,50$ & $395.009,10$ \\
\hline 2009 & $64.018,40$ & $354.019,20$ & $418.037,70$ \\
\hline 2010 & $71.218,00$ & $470.141,70$ & $541.359,70$ \\
\hline 2011 & $76.268,80$ & $508.204,60$ & $584.473,40$ \\
\hline 2012 & $84.431,30$ & $539.627,00$ & $624.058,30$ \\
\hline 2013 & $100.097,10$ & $631.864,90$ & $731.962,00$ \\
\hline 2014 & $104.941,10$ & $737.300,40$ & $842.241,50$ \\
\hline 2015 & $101.447,30$ & $803.314,30$ & $904.761,70$ \\
\hline 2016 & 81.587 & 951.356 & 1.032 .943 \\
\hline 2017 & 75.254 & 1.180 .969 & 1.256 .224 \\
\hline 2018 & 52.807 & 1.335 .815 & 1.388 .623 \\
\hline
\end{tabular}

Yukarıda da belirtildiği gibi açıkça görülmektedir ki havayolu taşımacılığına olan talep son yıllarda artmaktadır ve artmaya da devam edecektir. Bir havayolu şirketi talep ile arz dengesini kurmak için kapasitesini talebe göre dengelemek zorundadır. Havayolu taşımacılığında kapasiteyi ise filo planlama faaliyeti belirlemektedir. Şirketin filo planlamasındaki önemli karar süreçlerinden birisi uçak tip seçimidir. Bu doğrultuda havayolu şirketleri filosuna yeni katacağı uçakları seçerken birçok kriteri gözden geçirmeli ve operasyonlarına uygun siparişler vermelidir. Dolayısıyla uçak seçimi havayolu planlamanın ilk aşaması olarak tanımlanabilir.

Bu çalışmada birden fazla alternatifin belirli kriterlere göre değerlendirilmesine imkan veren çok kriterli karar verme (ÇKKV) yöntemleri kullanılarak bir Türk Havayolu Kargo firmasının uçak seçimi problemi ele alınmıştır. Kargo uçağı seçim kriterlerinin ağırlıklarını belirlemek amacıyla bulanık AHP yöntemi kullanılmıştır. Bulanık AHP uzmanların sözel değerlendirmelerine imkan veren ve bulanık sayılar ile bu sözel değerlendirmeleri analiz eden bir yöntemdir. Yöntemin basit olması ve etkin sonuçlar üretmesi nedeniyle kargo uçağı seçimi için yöneticilerin yararlanabileceği bir yöntem olduğu düşünülmüştür. Ayrıca yapmış olduğumuz literatür araştırmasına göre, klasik AHP yöntemi yolcu uçağı seçimi problemlerinin çözümünde kullanılmış olmasına rağmen, bulanık AHP yöntemi ile kargo uçağı seçimi problemini ele alan herhangi bir çalışmaya rastlanmamıştır. Farklı kargo uçă̆ı alternatifleri arasından firmanın operasyonlarına en uygun kargo uçağı modelinin seçilmesi için ise bulanık gri ilişkisel analiz (GIA) yöntemi kullanılmıştır. GIA yöntemi ÇKKV yöntemlerinden biri olup, tamamlanmamış veri veya eksik bilginin sebep olduğu belirsizlik durumunda ilişkilerin analizi için geliştirilmiş olan bir yöntemdir. Bulanık GIA yönteminin en büyük avantajı, göreceli olarak az miktarda verinin mevcut olduğu veya faktörler arasında çok miktarda değişkenlik olduğu durumlarda dahi problemlerin çözümü için başarılı sonuçlar üretebilmesidir (Yang ve Chen, 2005). Ayrıca, literatür araştırmamıza göre daha önce bulanık AHP ve bulanık GIA yöntemlerini kargo uçağı seçiminde kullanan bir çalışma bulunmaması sebebiyle de bu iki etkili yöntemin kargo uçağı seçim probleminin çözümünde kullanılmasına karar verilmiştir.

Bu çalışmada kargo uçağı tipi seçim probleminin çözümü için önemli olabilecek 16 adet farklı kriter, literatür taraması ve uzman görüşleri alınarak belirlenmiştir. Daha sonra kriterlerin önem derecelerini belirleyen ağırlık değerlerinin hesaplanabilmesi için bulanık AHP yöntemi kullanılmıştır. Bulanık AHP yöntemi ile önem dereceleri belirlenen kriterlere göre en uygun uçak seçimi bulanık GIA yöntemi ile gerçekleştirilmiştir. Kargo uçak tiplerinden, geniş gövde B777 F, A330-200F, B747-400F ve A310-300F uçakları arasından seçim yapılmıştır.

Bundan sonraki 2. Bölümde uçak seçimi ve çok kriterli karar verme (ÇKKV) ile ilgili bir literatür araştırması gerçekleştirilmiştir. Daha sonraki bölümlerde sırasıyla, çalışmada kullanılmış olan çözüm yöntemleri üzerinde durulmuş, 
Türk havayolu şirketinde kargo uçağı seçimi için ilgili yöntemler ile bir uygulama çalışması gerçekleştirilmiş ve son bölümde de sonuçlar ve bulgular üzerine tartışılmıştır.

\section{Literatür Taraması}

Uçak seçim kararı havayolu firmaları için oldukça önemli ve stratejik bir karardır. Havayolu firmasının hizmet verdiği pazarlara ve müşteri isteklerine uygun kriterler belirlemek ve bu kriterlere uygun uçak seçimi yapmak firmaya stratejik avantajlar kazandıracaktır. Uçak seçim problemi için kritik olan faktörlerin sayısının birden fazla olması ve bu kriterlerin birbirleri ile ilişkili olmaları uçak seçim probleminin bir ÇKKV problemi olarak ele alınmasına imkan vermektedir. Literatürde uçak seçim probleminin çözümü için farklı ÇKKV yöntemleri geliştirilmiştir.

$\mathrm{Bu}$ konuda son 15 yılda yapılmış olan çalışmalar incelendiğinde uçak seçimi ile ilgili farklı alanlarda ÇKKV yöntemlerinin kullanılmış olduğu gözlemlenmiştir. Bu çalışmalardan bazıları şu şekildedir; Bhadra (2003) uçak tipi seçim problemine ilgili uçuş hatlarındaki müşteri isteklerinin etkisini araştırmıştır. Çok terimli lojistik regresyon modelinin uygulaması sonucunda yolcular, uzaklık ve havaalanı merkezinin uçak tipi seçimi üzerinde azımsanmayacak bir etkisi olduğu gözlemlenmiştir. Harasani (2006) çalışmasında Suudi Arabistan'da yer alan bir havayolu firması için uçak filosu değerlendirme ve seçim problemini ele almıştır. Ulusal ve uluslar arası destinasyonlara hizmet verecek bu yeni havayolunun uçak filosunda yer alacak olan uçaklar belirlenirken öncelikle uçulacak olan destinasyonların fiziksel koşullarına ve yolcu talebi tahminlerine uygun uçak tipleri belirlenmiş daha sonrasında bu uçak tiplerinin maliyet ve performans açısından karşılaştırılması gerçekleştirilmiştir. Çalışmada beş yıllık dönem uzunluğu için simülasyon modeli oluşturularak problemin çözümü değerlendirilmiştir. Yeh ve Chang (2009), uçak tipi seçim problemi için yeni bir bulanık ÇKKV yöntemi geliştirmiştir. Geliştirilmiş olan yöntemde sübjektif değerlendirmelerin seçim kararına yansıtılabilmesini sağlamak için sözel değerlendirme ölçeği kullanılmıştır. Wang ve Chang, (2007), Tayvan Hava Kuvvetleri Akademisi'ndeki eğitimlerde kullanılacak uçakların seçim problemini ele almıştır. Problemin çözümünde kriterlerin önem dereceleri bir ÇKKV yöntemi ile belirlenmiş ve eğitim için uygun uçak modelinin seçimi için ise TOPSIS yöntemi kullanılmıştır. Çalışmada, uçak modelinin seçimi için etkili olabilecek 16 kriter belirlenmiştir. Özdemir vd. (2011) çalışmalarında Analitik Ağ Süreci (ANP) yöntemini kullanarak Türk Havayolları (THY) firmasının uçak seçim problemini ele almışlardır. Uçak seçimi için kritik olabilecek 16 kriteri zaman, maliyet ve fiziksel özellikler olarak üç ana kriter altında toplanmışlardır. Gomes vd. (2014), çalışmalarında bir lojistik firmasının uçak seçim problemini ele almışlardır. Çalışmanın uygulama bölümünde sekiz farklı tipteki uçak modelini 11 kriter ile değerlendirmişlerdir. Problemin çözümü için bulanıklık durumunda kalitatif ve kantitatif kriterlerin değerlendirilmesine aynı anda izin veren NAIADE (Novel Approach to Imprecise Assessment and Decision Environments) isimli ÇKKV yöntemini kullanmışlardır. Dožić ve Kalić (2014), belirli rota ağlarında yolcu talebinin tahmin edildiği durumlar için uçak tipi seçim problemini ele almıştır. Problemin çözümünde ÇKKV yöntemlerinden biri olan AHP yöntemini kullanmışlardır. Çalışmanın uygulamasını Güneydoğu Avrupa bölgesinde hizmet veren yerel bir havayolu firmasında yapmışlar ve kısa mesafe için uçak tipi problemini çözmüşlerdir. Çalışmada, koltuk kapasitesi, fiyat, bagaj kapasitesi, MTOW (maksimum kalkış ağırlığı), ödeme koşulları ve toplam c/ASM (koltuk/ mil toplam operasyon maliyeti) gibi seçim kriterleri kullanılmıştır. Yapmış oldukları duyarlılık analizi ile ikili karşılaştırma matrisindeki bir kriterin önem derecesini değiştirerek (diğerlerini sabit tutarken), uçak tipi seçimindeki olası değişimleri gözlemlemişlerdir. Dožić ve Kalić (2015), çalışmalarında uçak tipi seçimi probleminin çözümü için AHP ve ESM (Eşit Takas Yöntemi-Even Swap Method) yöntemlerini karşılaştırmışlardır. Çalışmanın uygulama bölümünde yerel havayolu firmasının yakın mesafedeki (en fazla $800 \mathrm{~km}$ ) uçuş rotalarında kullanabileceği küçük uçakların seçim problemi ele alınmıştır. Uçak tipi seçimi için Dožić ve Kalić (2014) tarafından kullanılan kriterler bu çalışmada da kullanılmıştır. Yöntemlerin arasındaki farklılıkları ölçümlemek üzere farklı duyarlılık analizleri uygulamışlardır. Ödeme koşulu kriterinin önem derecesi değiştirilerek yöntemlerin bu değişime tepkileri ölçülmüştür. AHP yönteminin bu değişime duyarlı olduğu gözlemlenirken bu değişimin sonucunun ESM yönteminin sonuçlarını etkilemediği gözlemlenmiştir.

Tablo 3. Uçak Seçim Kararı Ile Ilgili Çalışmalarda Kullanılan Yöntemlere Ait Özet Literatür

\begin{tabular}{|l|l|}
\hline Yöntem & Yazar \\
\hline Tip 2 Bulanık TOPSIS & Deveci vd. (2017) \\
\hline AHP & Dožić ve Kalić (2014) \\
\hline AHP ve ESM & Dožić ve Kalić (2015) \\
\hline Yeni bir ÇKKV Yöntemi & Yeh ve Chang (2009) \\
\hline TOPSIS & Wang ve Chang, (2007) \\
\hline NAIADE & Gomes vd. (2014) \\
\hline ANP & Özdemir vd. (2011) \\
\hline $\begin{array}{l}\text { Bulanık ANP ve Genelleştirilmiş̧ } \\
\text { Choquet Integrali }\end{array}$ & Özdemir ve Basligil (2016) \\
\hline Bulanık AHP & Dožić ve Kalić (2018) \\
\hline
\end{tabular}

Özdemir ve Basligil (2016), THY firmasının orta sınıf standart gövde, tek koridorlu uçak seçim problemini ele almıştır. Problemin çözümü için bulanık ANP ve Choquet Integral yöntemleri geliştirilmiş ve bu yöntemlerin sonuçları 
bulanık AHP yöntemi ile karşılaştırılmıştır. Çalışmada, Maliyet (satın alma maliyeti, operasyon ve yedek parça maliyeti, tamir-bakım maliyeti, hurda maliyeti), Zaman (teslimat zamanı, ekonomik ömür), Fiziksel Özellikler vd. (boyut, güvenlik, güvenilirlik, hizmet kalitesi için uygunluk) olmak üzere üç ana kriter ve on alt kriterin firmanın uçak seçim kararı üzerindeki önem dereceleri belirlenmiş ve uçak seçim problemi çözülmüştür.

Dožić vd. (2018) yolcu uçak seçimi için bulanık AHP yöntemini kullanmıştır. Uçak model özellikleri, maliyet ve katma değer yaratan özellikler olarak 3 ana kriter ve bunların altında yer alan 10 alt kritere göre yolcu uçak modellerini değerlendirmişlerdir. Tablo 3'de uçak seçimi kararı ile ilgili çalışmalarda kullanılan yöntemler yer almaktadır. Buradan da görülebileceği üzere bulanık AHP ve bulanık GIA yöntemlerini kombine eden bir yöntem kargo uçağı seçimi problemi için daha önce kullanılmamıştır.

\section{3. Çözüm Yöntemleri}

$\mathrm{Bu}$ çalışmada iki aşamalı bir çözüm yöntemi kullanılmıştır. İlk aşamada bulanık AHP yöntemi ile kriter önem derecelerinin belirlenmiştir. İkinci aşamada ise bulanık gri ilişkisel analiz (GIA) yöntemiyle alternatifler değerlendirilmiştir.

\subsection{Analitik Hiyerarşi Prosesi (AHP) Yöntemi}

Analitik Hiyerarşi Prosesi (AHP) Saaty tarafından 1980 yılında geliştirilmiş olan ve literatürde en çok kullanılan ÇKKV yöntemlerinden birisidir. AHP yönteminde karmaşık birimlerin hiyerarşik yapısı, ikili karşılaştırma, çok sayıda kriter, ağırlık katsayılarının oluşturulmasında özvektör ve tutarlılık katsayısı kullanılmaktadır. AHP yöntemi geliştirildiği yıllardan itibaren karar alternatiflerinin değerlendirilmesinde ve karar verme problemlerinin çözümünde etkin olarak kullanılmaktadır. Karmaşık karar verme problemlerinde AHP yönteminin kullanılması sayesinde karar alternatiflerine ve kriterlerine göreceli önem değerlerinin belirlenmesi sağlanmaktadır. AHP yöntemi yapısında yer alan ikili karşılaştırma özelliği sayesinde uzman görüşleri alınarak nitel ve nicel kriterlerin önem derecelerinin karşılaştırılmasına imkan vermektedir. Böylece karmaşık gerçek hayat problemlerinde uzman görüşlerinin problemin çözümüne dahil edilmesini sağlamaktadır (Chai vd., 2013). AHP yönteminin çözüm adımları 5 adımda özetlenebilir (Göksu ve Güngör, 2008) :

1.adım: Problemin ortaya konması ve hiyerarşik yapıda en üstte yer alacak olan hedefin belirlenmesi.

2. adım: Problem hiyerarşisinin oluşturulması. Burada en üstte hedef amaç yer alırken diğer kademelerde kriterler, alt kriterler ve alternatifler yer almaktadir.

3. adım: Kriterler, alt kriterler ve alternatifler için ayrı ayrı ikili karşılaştırma matrisleri oluşturulur.

4.adım: İkili karşılaştırma matrislerinin karar vericiler tarafından değerlendirilmesinin ardından bu sonuçlar kullanılarak göreli önem vektörü (ağırlık vektörü) hesaplanır.

5. adım: Hesaplamaların tutarlılığını test etmek amacıyla tutarlılık oranı hesaplanır. Tutarlı olmama durumunda ikili karşılaştırmalar tekrar gözden geçirilerek yeniden hesaplanır.

AHP yöntemi karmaşı problemlerin bileşenlerinin ve değişkenlerinin hiyerarşik yapıda ifade edilerek alternatiflerin karşılaştırmalı önem derecelerine göre değerlendirilmesine imkan vermektedir. Ancak klasik AHP yönteminin belirsizlik içeren insan kararlarını ve değerlendirmelerini tam olarak yansıtamaması nedeniyle ikili karşılaştırmaların sözel ifadeler ile değerlendirildiği bulanık AHP yöntemi geliştirilmiştir (Özen ve Koçak, 2017).

\subsection{Bulanık AHP Yöntemi}

Birçok gerçek hayat karar problemi yapısında bulanıklık ve belirsizlik bulundurmaktadır. Bu sebeple bu tür problemlerin çözümünde belirsizlik durumunun üstesinden gelebilen çözüm yöntemleri tercih edilmelidir (Kabir ve Sumi, 2014: 719) Bulanık küme teorisi ilk defa Zadeh (1965) tarafından geliştirilmiştir. Bulanık teoriye göre insan düşüncelerindeki anahtar ifadelerin rakamsal ifadeler yerine sözel ifadeler ile değerlendirilmesi daha doğrudur ve sözel ifadelerin bulanık küme değerleriyle sayısallaştırılması mümkündür (Srichetta ve Thurachon, 2012). Literatürde, kullanım ve hesaplama kolaylığ1 sağlaması nedeniyle genellikle üçgensel bulanık sayı değerleri kullanmaktadır. Üçgensel bulanık sayı $\widetilde{\mathrm{M}}$ değerleri (1,m,n) sembolleriyle ifade edilmektedir. Bu parametredeki "l” mümkün alt sınırı, "m” en mümkün değeri, "u” üst sınır değerini ifade etmektedir. $\widetilde{\mathrm{M}}=(l, m, u)$ üçgensel bulanık sayısının ait olduğu üyelik fonksiyonu aşağıdaki gibidir (Sen ve Çınar, 2010: 2045).

$\mu_{\widetilde{M}}(x)=\left\{\begin{array}{cc}0 & x<l \\ (x-l) /(m-l) & l \leq x \leq m \\ (u-x) /(u-m) & m \leq x \leq u \\ 0 & x>u\end{array}\right.$

Bulanık AHP yöntemi, klasik AHP yöntemine göre sözel değerlendirmeleri probleme dahil edebilme özelliğine sahiptir ve sözel ifadelerin muğlaklığını daha iyi bir şekilde çözüme yansıtabilmektedir. Bulanık AHP' de bulanık sayılar tarafından ifade edilebilen sözel ifadelerle ikili karşılaştırmalar yapılmaktadır. Bu sayede karar vericiler iki değişkeni birbirine göre önem derecelerini bulanık küme sözel değerleriyle ifade edebilmektedir. Tablo 4 'de sözel ifadelerin bulanık sayılara dönüşümü için geliştirilmiş olan bulanık AHP önem ölçeği yer almaktadır (Göksu ve Güngör, 2008:11). 
Tablo 4. Bulanık AHP Önem Ölçeği

\begin{tabular}{|c|c|c|}
\hline Açıklama & Önem Derecesi & Önem Derecesi Eşleniği \\
\hline Eşit Önemli & $(1,1,1)$ & $(1,1,1)$ \\
\hline Daha Önemli & $(2 / 3,1,3 / 2)$ & $(2 / 3,1,3 / 2)$ \\
\hline Çok Daha Önemli & $(3 / 2,2,5 / 2)$ & $(2 / 5,1,2 / 3)$ \\
\hline Çok Fazla Önemli & $(5 / 2,3,7 / 2)$ & $(2 / 7,3,2 / 5)$ \\
\hline Kesin Önemli & $(7 / 2,4,9 / 2)$ & $(2 / 9,4,7)$ \\
\hline \multicolumn{3}{|c|}{ Kaynak: $($ Chang,1996: 652) } \\
\hline
\end{tabular}

Bulanık AHP, Saaty tarafından önerilen olan klasik AHP yönteminin geliştirilmiş halidir. AHP yönteminde bulanık üçgensel sayılar ilk defa Van Laarhoven ve Pedrycz (1983) tarafından kullanılmıştır ve daha sonra bu yöntemin uygulanışı ile ilgili literatürde farklı yaklaşımlar geliştirilmiştir. Bunlardan bazıları, geometrik ortalamalar yöntemi, logaritmik küçük kareler yönteminin bulanık modifikasyonu, direkt bulanıklaştırma yöntemi, bulanık tercih programlama, bulanık küçük kareler yöntemi ve sentetik genişletilmiş analiz yöntemidir. Chang (1996) tarafından geliştirilmiş olan $\mathrm{S}_{\mathrm{i}}$ sentetik mertebe değeri ile ikili karşılaştırmaların yapıldığı "Mertebe Analiz Tekniği” literatürde yaygın olarak kullanılan yöntemdir. Mertebe analiz tekniğinin literatürde yaygın olarak kullanılmasının nedeni diğer bulanık AHP yöntemlerine kıyasla daha kolay uygulama adımlarına sahip olması ve çözüm adımlarının klasik AHP yöntemine benzemesidir. Ancak Wang vd. (2008) tarafından yapılmış olan bir çalışmada bu yöntem ile geliştirilmiş olan olabilirlik dereceleri iki üçgensel bulanık sayının karşılaştırılmasına imkan vermesine rağmen öncelik vektörleri kriterlerin ya da alternatiflerin göreceli önemini belirlemekte hatalı olabileceğini öne sürülmüştür (Şen ve Çınar, 2010: 2045; Kabir ve Sumi, 2014: 720; Dožić vd., 2018: 167). Buna dayanılarak bu çalışmada mertebe analizi yönteminin modifiye edilmiş hali kullanılmıştır. Bu yöntemde, Chang (1996) tarafından geliştirilen mertebe yaklaşımına göre hesaplanan $\mathrm{S}_{\mathrm{i}}$ sentetik mertebe değerleri kullanılarak alternatiflerin göreceli önem değerleri belirlenirken, Liou ve Wang (1992) tarafindan önerilmiş olan toplam entegral yöntemi kullanılarak alternatifler sıralanmıştır. Çalışmada kullanılmış olan Bulanık AHP yönteminin uygulama adımları aşağıdaki gibidir (Kabir ve Sumi, 2014: 719-720):

Adım 1: İlk adımda her bir ikili karşılaştırma için bulanık sentetik mertebe değerinin hesaplanmaktadır. Ölçüt i 'ye ait bulanık sentetik mertebe değeri eşitlik(1) yardımıyla hesaplanır.

$$
S_{i}=\sum_{j=1}^{m} M_{g i}^{j} \otimes\left[\sum_{i=1}^{n} \sum_{j=1}^{m} M_{g i}^{j}\right]^{-1}
$$

Eşitlik (1)'de yer alan $\sum_{j=1}^{m} M_{g i}^{j}$ değerini hesaplamak için, m değeri üzerinde bulanık toplama işlemi belirli bir matris için aşağıdaki gibi hesaplanır,

$$
\sum_{j=1}^{m} M_{g i}^{j}=\left(\sum_{j=1}^{m} l_{j}, \sum_{j=1}^{m} m_{j}, \sum_{j=1}^{m} u_{j}\right)
$$

$\left[\sum_{j=1}^{n} \sum_{j=1}^{m} M_{g i}^{j}\right]^{-1}$ ifadesini elde etmek için $M_{g i}^{j}(j=1,2, \ldots, m)$ değerleri ile bulanık toplama işlemi gerçekleştirilir ve Eşitlik (3) verilen denklemdeki vektörün tersi Eşitlik (4)'deki gibi hesaplanır.

$$
\begin{gathered}
\sum_{i=1}^{n} \sum_{j=1}^{m} M_{g i}^{j}=\left(\sum_{i=1}^{n} l_{i}, \sum_{i=1}^{n} m_{i}, \sum_{i=1}^{n} u_{i}\right) \\
{\left[\sum_{j=1}^{n} \sum_{j=1}^{m} M_{g i}^{j}\right]^{-1}=\left(\frac{1}{\sum_{i=1}^{n} u_{i}}, \frac{1}{\sum_{i=1}^{n} m_{i}}, \frac{1}{\sum_{i=1}^{n} l_{i}}\right)}
\end{gathered}
$$

Adım 2: İkinci adımda bulanık sentetik mertebe değerlerinin $\left(M_{i}\right)$ sıralamasını yapmak amacıyla olabilirlik dereceleri hesaplanır. Bu aşamada Chang (1996)'nın geliştirmiş olduğu yönteme göre iki farklı sentetik mertebe değeri olmak üzere, bu değerlerin karşılaştırılabilmesi için $M_{1}=\left(l_{1}, m_{1}, u_{1}\right)$ ve $M_{2}=\left(l_{2}, m_{2}, u_{2}\right)$ 'nin iki farklı üçgensel bulanık sayı olduğu durumda, $M_{2}=\left(l_{2}, m_{2}, u_{2}\right) \geq M_{1}=\left(l_{1}, m_{1}, u_{1}\right)$ 'nin olabilirlik derecesi Eşitlik (5)'deki gibi ifade edilir.

$$
V\left(M_{2} \geq M_{1}\right)=\mu_{M 1}(d)=\left\{\begin{array}{cl}
1 & \text {, if } m_{2} \geq m_{1} \\
0 & \text {, if } l_{1} \geq u_{2} \\
\frac{l_{1}-u_{2}}{\left(m_{2}-u_{2}\right)-\left(m_{1}-l_{1}\right)} & , \text { otherwise }
\end{array}\right.
$$

Eşitlik (5)'deki $d$ değeri $\mu_{M 1}$ ve $\mu_{M 2}$ arasındaki en yüksek kesişim noktasının ordinatıdır ve aşağıdaki Eşitlik (6)' daki gibi ifade edilmektedir.

$$
V\left(M_{2} \geq M_{1}\right)=\operatorname{hight}\left(M_{1} \cap M_{2}\right)=\mu_{M 1}(d) .
$$

Buna ilaveten, $M_{1}$ ve $M_{2}$ değerlerini kiyaslayabilmek için $V\left(M_{2} \geq M_{1}\right)$ ve $V\left(M_{1} \geq M_{2}\right)$ değerlerinin bilinmesi gerekmektedir. Chang (1996) tarafından geliştirilmiş olan yöntem literatürde çok sıklıkla kullanılmış olmasına rağmen bu yöntemin bazı dezavantajları bulunmaktadır. Wang vd. (2008) tarafından yapılmış olan çalışmaya göre Chang (1996) tarafından önerilen bu yöntemde hesaplanan sentetik değerler sadece iki üçgensel bulanık sayının karşılaştırılması için kullanılabilir ve sayıların göreceli önem değerlerini hesaplamak için yetersizdir. Ayrıca bu yönteme göre bazı durumlarda kriterlerin ağırlık değerleri sıfır olarak hesaplandığı için değerlendirmeden çıkartılması söz konusu olmaktadır (Vahidnia vd., 2009: 3050). Bu nedenle, bu çalışmada ilerleyen adımlarda Liou ve Wang (1992) tarafindan geliştirilmiş olan toplam entegral yöntemi kullanılarak bulanık sentetik değerlerin göreceli öncelik değerleri Eşitlik (7) yardımıyla belirlenmiştir. 
Buradaki $\alpha$ değeri karar vericilerin iyimserlik derecesini ifade eden iyimserlik katsayısıdır. $\alpha=[0,1]$ olmak üzere karar vericilerin iyimserlik derecesi arttıkça 1'e yaklaşırken, azaldıkça 0'a yaklaşmaktadır.

$$
\begin{gathered}
I_{T}^{\alpha}\left(S_{i}\right)=\frac{1}{2} \alpha\left(m_{i}+u_{i}\right)+\frac{1}{2}(1-\alpha)\left(l_{i}+m_{i}\right) \\
=\frac{1}{2}\left[\alpha u_{i}+m_{i}+(1-\alpha) l_{i}\right]
\end{gathered}
$$

Adım 3: Bu adımda bulanık karşıllaştırma matrisi A'ya ait normalize ağırlık vektörü, $W=\left(w_{1}, w_{2}, \ldots \ldots, w_{3}\right)^{T}$, Eşitlik (8) ile hesaplanır. Elde edilen ağırlıklar hiyerarşik olarak sentezlenerek nihai alternatif ağırlıkları elde edilir. Burada hesaplanan $\mathrm{W}$ ağırlık vektörü bulanık sayı değildir.

$$
w_{x}=\frac{I_{T}^{\alpha}\left(S_{x}\right)}{\sum_{k=1}^{n} I_{T}^{\alpha}\left(S_{k}\right)} \quad x=1, \ldots . . n .
$$

Adım 4: Bulanık AHP tarafından geliştirilmiş olan çözümlerin geçerliliğinin kontrol edilmesi amacıyla tutarlılık oranı (CR) hesaplanmıştır. Bulanık AHP yönteminde CR değerlerinin hesaplanabilmesi için öncelikle bulanık karar matrisi değerleri Eşitlik (9) ile durulaştırılmıştır.

$$
P(\widetilde{M})=M=\frac{l+4 m+u}{6}
$$

Karar matrisi değerlerinin hepsi durulaştırıldıktan sonra CR değerinin hesaplanabilmesi için klasik AHP yöntemindeki adımlar takip edilmiştir.

$$
\begin{gathered}
C I=\frac{\left(\lambda_{\text {maks }}-n\right)}{(n-1)} \\
C R=C I / R I
\end{gathered}
$$

Buna göre $\lambda_{\text {maks }}$ değeri en büyük özdeğeri ifade etmek üzere, $C I$ değeri Eşitlik (10) ve $C R$ değeri Eşitlik (11) kullanılarak hesaplanmıştır. Rassallık indeks değerleri (RI) için Tablo 5 ‘deki değerler kullanılmıştır.

Tablo 5. Farklı Matris Boyutları için Geliştirilmiş Rassallık Indeks (RI) Değerleri

\begin{tabular}{|c|c|c|c|c|c|c|c|c|c|}
\hline$n$ & 1 & 2 & 3 & 4 & 5 & 6 & 7 & 8 & 9 \\
\hline R.I. & 0 & 0 & 0,58 & 0,90 & 1,12 & 1,24 & 1,32 & 1,41 & 1,45 \\
\hline \multicolumn{10}{|c|}{ Kaynak: (Saaty, 1994: 42) }
\end{tabular}

Karar matrislerinin uygunluğunun kabulü için CR değerlerinin 0,10'dan küçük olup olmadığı kontrol edilmiştir (Kwong ve Bai, 2003; Kabir ve Sumi, 2014; Şen ve Çınar, 2010).

Bulanık AHP, 1983 yılından beri literatürde faklı endüstrilerdeki tedarikçi seçimi, yer seçimi, proje seçimi, personel seçimi, enerji kaynağı seçimi, makine seçimi vb. birçok karar verme problemlerinin çözümünde uygulanmıştır. Kubler vd. (2016) tarafından yapılmış olan literatür taramasına göre 2004 yılından bu tarihe kadar bulanık AHP yöntemini kullanan 190 adet çalışma bulunmaktadır. Bunlardan bazıları şöyledir: Chan vd. (2008) küresel tedarikçi seçim probleminin çözümü için bulanık AHP yöntemini kullanmıştır. Srdjevic ve Medeiros (2008), Brezilya' daki bir nehir için su yönetimi planlarının değerlendirilmesini bulanık AHP ile gerçekleştirmiştir. Vahidnia vd. (2009) bulanık AHP yöntemi ile hastane yer seçimi problemini çözmüştür. Heo vd. (2010) yenilenebilir enerji kaynaklarının yayılım programlarının değerlendirilmesi için bulanık AHP yöntemini uygulamıştır. Şen ve Çınar (2010) çalışmalarında operatörlerin tercihi ve işlere atanması için bulanık AHP yönteminden yararlanmıştır. Kabir ve Hasin (2011) klasik AHP ve bulanık AHP yöntemlerini çok kriterli stok sınıflandırması probleminin çözümünde karşılaştırmıştır. Kabir ve Sumi (2014) elektrik istasyonlarının yer seçimi problemi için bulanık AHP ve PROMETHEE yöntemlerini kullanmıştır. Mangla vd. (2015) yeşil tedarik zincirinde risk analizi ölçümü için bulanık AHP yönteminden yararlanmıştır. Singh vd. (2018) küresel bir tedarik zinciri için depo yeri seçimi problemini bulanık AHP yöntemi ile çözmüştür. Dozic vd., (2018) yolcu uçağı seçimi problemini yolcuların tercihlerini de göz önüne alarak bulanık AHP yöntemiyle çözmüştür. Bu örneklerden de anlaşılacağı gibi bulanık AHP yöntemi birçok farklı alandaki karar süreçlerinde başarılı bir performans göstermiştir.

\subsection{Bulanık Gri İlişkisel Analiz Yöntemi}

Gri ilişkisel analiz (GİA), belirsizlik durumunda ilişkilerin analizi için kullanılan bir yöntemdir. 1982 yılında J.L. Deng tarafindan geliştirilmiş olan Gri Sistem Teorisine dayanan GIA yöntemi, bilgilerin belirsiz olması durumunda veya eksik bilgi olduğunda karar vermeye yardımcı olmaktadır (Senger ve Albayrak, 2016). Gri sistem teorisine göre kusursuz ve tam bilgiye sahip olan bir sistem beyaz renk ile sembolize edilirken, tam tersi durumdaki sistemler siyah renk ile sembolize edilmektedir. Bu teoriye göre eksik veya belirsiz bilgilerin olduğu sistemler gri renk ile sembolize edilmektedir (Avcı vd. 2017). Genellikle ÇKKV yöntemlerinde kriterler maksimizasyon veya minimizasyon amaçlı olarak değerlendirilir. Ancak bu yöntemler kesin üst limit, optimal değer veya alt limit üzerinden değerlendirmeyi gerektiren kriterlerin değerlendirmesinde yetersiz kalabilmektedir. GIA yöntemi kriterleri değerlendirirken diğer yöntemlerdeki bu yetersizliği telafi edebilmektedir (Özcan vd. 2011).

Bulanık GIA yöntemini kullanmış olan çalışmalar da şu şekilde özetlenebilir. Goyal ve Gorever (2012) çalışmalarında bulanık GIA yöntemini kullanarak gelişmiş üretim sistemlerinin tercihi için bir model geliştirmiştir. Çalışmanın uygulama bölümünde literatürden iki farklı yöntem ile bulanık GIA yöntemini karşılaştırmışlardır. Bulanık GIA'nın belirsizlik koşulları altında az veri ile etkin sonuç vermesinin diğer yöntemlere karşı avantajı olduğunu belirtmişlerdir. Gumus vd. (2013), bulanık AHP ve bulanık GIA yöntemlerini birlikte kullanarak Türkiye'deki hidrojen 
enerji depolama yöntemlerini değerlendirmişler. Ulutaş vd. (2018) çalışmalarında bulanık AHP ve bulanık GIA yöntemlerini birlikte kullanarak personel seçimi problemini ele almıştır. Personel seçiminde kullanılacak olan kriterler bulanık AHP yöntemi ile belirlendikten sonra bulanık GIA yöntemiyle aday personel değerlendirilerek seçim yapılmıştır.

Bulanık gri ilişkisel analizin uygulama adımları aşağıdaki gibi özetlenebilir (Gumus vd., 2013: 3022; Ulutaş vd., 2018: 227).

Adım 1: Karar matrisinin oluşturulması. $\tilde{x}_{i j}$ 'in i. satır ve j. sütundaki değeri ifade ettiği karar matrisi oluşturulur. Buradaki $\tilde{x}_{i j}=\left(l_{i j}, m_{i j}, u_{i j}\right)$ bir üçgensel bulanık sayıyı ifade etmektedir. Alternatiflerin kriterlere göre değerlendirildiği karar matrisinde Tablo 6 ‘daki sözel değerlendirme ölçeği kullanılmıştır (Goyal ve Grover, 2012: 287).

Tablo 6. Bulanık Gri İlişkisel Analiz Sözel Değerlendirme Ölçeği

\begin{tabular}{|c|c|}
\hline Açılama & Bulanık Sayı Dĕgeri \\
\hline Düşük & $(0 ; 0,25 ; 0,50)$ \\
\hline Orta & $(0,30 ; 0,50 ; 0,70)$ \\
\hline Yüksek & $(0,50 ; 0,75 ; 1)$ \\
\hline Çok Yüksek & $(0,70 ; 1 ; 1)$ \\
\hline \multicolumn{2}{|c|}{ Kaynak: (Goyal ve Grover, $2012: 287)$} \\
\hline
\end{tabular}

Adım 2: Normalize karar matrisi R 'nin oluşturulması. Bu adımda klasik GIA yönteminde olduğu gibi hedef değerin maksimizasyon veya minimizasyon olmasına göre iki farklı formül yardımıyla normalizasyon işlemi gerçekleştirilmektedir. Buna göre, her bir değişken $\tilde{x}_{i j}=\left(l_{i j}, m_{i j}, u_{i j}\right)$ olmak üzere eğer kriter faydalı ise eşitlik (12) ile, eğer maliyet kriteriyse eşitlik (13) ile normalize edilir.

$$
\begin{gathered}
\tilde{r}_{i j}=\left(\frac{l_{i j}}{u_{j}^{+}}, \frac{m_{i j}}{u_{j}^{+}}, \frac{u_{i j}}{u_{j}^{+}}\right), i=1, \ldots \ldots m ; j=1, \ldots . n \\
\tilde{r}_{i j}=\left(\frac{l_{j}^{-}}{u_{i j}}, \frac{l_{j}^{-}}{m_{i j}}, \frac{l_{j}^{-}}{l_{i j}}\right), i=1, \ldots . m ; j=1, \ldots . n
\end{gathered}
$$

Yukarıdaki eşitlik (12) ve (13)'deki $u_{j}^{+}=\operatorname{maks}_{i}\left\{u_{i j}\right\}$ ve $l_{j}^{-}=\min _{i}\left\{l_{i j}\right\} \forall i \quad i=1, \ldots . n$ ifade etmektedir.

Adım 3: Referans serilerin belirlenmesi. Referans seri, $\tilde{r}_{0 j}=\operatorname{maks}\left(\tilde{r}_{i j}\right)$ ve $j=1, \ldots \ldots n$ olmak üzere eşitlik (13)'daki gibi belirlenir.

$$
\tilde{R}_{0}=\left[\tilde{r}_{01}, \tilde{r}_{02}, \ldots \ldots, \tilde{r}_{0 n}\right]
$$

Adım 4: Mesafeler matrisinin oluşturulması. Referans seri değerleri ile karar matrisi değerleri arasındaki mesafeleri ifade eden $\tilde{\delta}_{i j}$ mesafeler matrisi eşitlik (15) ile hesaplanır.

$$
\tilde{\delta}_{i j}=\left|\tilde{r}_{0 j}-\tilde{r}_{i j}\right|
$$

Adım 5: Bulanık gri ilişkisel katsayı matrisinin hesaplanması. Bulanık gri ilişkiler katsayısı $\tilde{\delta}_{\text {maks }}=\operatorname{maks}\left(\tilde{\delta}_{i j}\right)$ ve $\tilde{\delta}_{\min }=\min \left(\tilde{\delta}_{i j}\right)$ olmak üzere eşitlik (16) ile hesaplanır. Buraki $\xi$ değeri belirleyici katsayısı sabit bir değer olup [0,1] arasında bir değer almaktadır. Literatürdeki çalışmalarda çoğunlukla 0,5 olarak alınması uygun bulunduğu için bu çalışmada da 0,5 olarak kabul edilmiştir.

$$
\tilde{\tilde{\delta}}_{i j}=\frac{\widetilde{\delta}_{\min }+\xi \widetilde{\delta}_{m a k s}}{\widetilde{\delta}_{i j}+\xi \widetilde{\delta}_{m a k s}}
$$

Adım 6: Bulanık gri ilişkisel katsayı matrisi değerleri eşitlik (17) yardımıyla durulaştırılır.

$$
\delta_{i j}=\frac{l_{i j}+2 m_{i j}+u_{i j}}{4}
$$

Adım 7: Gri ilişki derecelerinin hesaplanması. Gri ilişki dereceleri, $\gamma_{i}$ değeri i. elemanın bulanık gri ilişki derecesini ifade etmek üzere eşitlik (18) ile hesaplanmaktadır. Burada kriterlerin önem derecelerinin farklı olması nedeniyle $w_{j}$ değeri j kriterinin ağırlığını ifade etmektedir ve $\sum_{j=1}^{n} w_{j}=1$ 'dir.

$$
\gamma_{i}=\sum_{j=1}^{n} w_{j} \delta_{i j} \quad i=1 \ldots, m
$$

\section{Kargo Uçak Tipi Seçim Problemi Uygulama}

Bu çalışmada Türkiye'de faaliyet gösteren İstanbul AHL merkezli bir havayolu kargo firması ele alınmıştır. Firma bağlı olduğu grubun yolcu uçakları ile birlikte toplamda 300'ün üzerinde noktaya kargo taşımacılığı yapabilmektedir. Hava taşımacılığına olan yüksek talep nedeniyle sadece kargo taşımacılığı yapılan tarifeli seferleri de bulunmaktadır. Böylece bazı palet ve konteyner tipleri hem Ana Güvertede (Main Deck) hem de Alt Güvertede (Lower Deck) taşınabilmektedir. Firma genel kargo taşımacılığının yanında soğuk zincir taşımacılığı, canlı hayvan taşımacılığı, değerli eşya taşımacılığı, bozulabilir ürün taşımacılığı ve cenaze taşımacılığı gibi özel kargo taşımacılıklarını da yerine getirebilmektedir. Bunun yanı sıra yurtiçi ve yurtdışı posta taşımacılığı da yapmaktadır. İşletme bunun haricinde uçmadığı noktalara kargo taşıyabilmek için interline ve SPA anlaşmaları düzenlemiştir. Ayrıca havalimanından kapıya teslim yapabilmek için intermodal taşımacılık yapabilmektedir.

İstanbul tarihi öneminin yanı sıra coğrafi özellikleriyle de stratejik önem kazanmıştır. Karayolu taşımacılığındaki konumu ve ipek yolu üzerinde oluşu tarih boyunca tüm medeniyetler için bir merkez olmuştur. Havayolu taşımacılığında 
ise bu önem daha da artmaktadır. İstanbul çıkışlı dört saatlik bir uçuşla 50 kadar ülkeye uçulabilmektedir. Firmanın da İstanbul merkezli olması bu coğrafi avantajdan yararlanabilmesine olanak sağlamaktadır.

Çalışmada havayolu işletmesinin kargo uçağı olarak kullanacağı uçak tipi seçimi dikkate alınmıştır. Kargo uçak tiplerinden, geniş gövde B777 F, A330-200F, B747-400F ve A310-300F uçakları arasından seçim yapılmıştır.

Bu çalışmada sadece yük taşımacılığı için uygun olan kargo uçak tipleri arasından tercih yapılmıştır. Bunun nedeni, her ne kadar yolcu uçaklarının Alt Güvertesinde (Lower Deck) ve Yığma Kompartımanında (Bulk Cargo Compartment) kargo taşımacılığı yapılsa da Ana Güvertede (Main Deck) sadece yolcu taşımacılığı yapılabilmektedir, kargo taşınamamaktadır. Bunun yanı sıra yolcu taşımacılığı dünya genelinde çift yönlü olarak gerçekleşmektedir. Giden yolcu aynı zamanda geri dönmektedir. Böyle bir taşımacılık türünde alt güvertede kargo taşınabilmektedir. Halbuki ticaretin gereği olarak kargo taşımacılığı tek yönlü gerçekleşmektedir. Örneğin, Amerika Birleşik Devletleri, New York ve Çin, Hong Kong'da bulunan iki farklı tedarikçiden alınan yükler ekonomisi ithalata dayalı Suudi Arabistan Riyad'a (RUH)'a gönderilmek istendiğinde eğer bu kargo taşımacılığında yolcu uçağı tercih edilirse asıl amacı yolcu taşımak olan bu uçaklar İstanbul Havalimanından kalkar, John F. Kennedy Havalimanına gider ve dönüşünü yine New York' dan İstanbul olarak gerçekleştirir. Aynı şekilde bir başka İstanbul kalkışlı bir yolcu uçağı Hong Kong'a gider ve İstanbul'a geri döner. Daha sonra alt güvertesinde taşınan kargo yükleri İstanbul'da birleştirilerek, Suudi Arabistan Riyad'a (RUH) tek yönlü olarak kargo uçağı ile taşınır. Bu taşımacılığın devamında kullanılan kargo uçağı Şekil 2'deki rotayı izleyerek İstanbul'dan Uganda'ya (EBB) uçmakta, oradan aldığı kargoyu Avrupa'da Hollanda' ya (MST) getirmekte, Hollanda'dan aldığı yükü ise İstanbul'a getirmektedir.

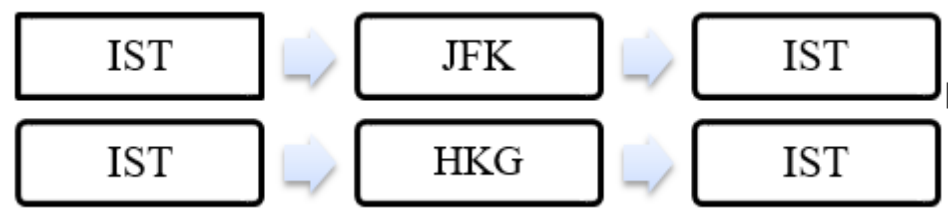

Şekil 1. Çift Yönlü Yolcu Uçağı Destinasyonu

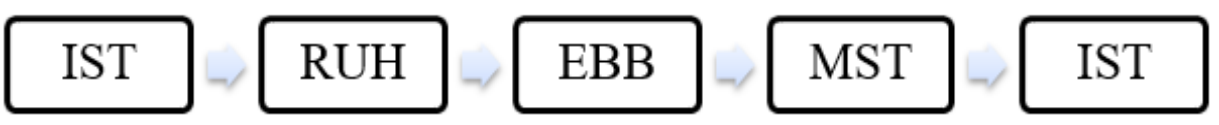

Şekil 2. Tek Yönlü Kargo Uçağı

Yukarıdaki şekillerden de görülebildiği gibi her ne kadar yolcu uçaklarında alt güvertede kargo taşımacılığı mümkün olsa da, yolculardaki çift yönlü hareketin aksine kargoda tek yönlü hareket bulunmaktadır. Bu da yolcu uçaklarıyla getirilen kargonun dünyadaki tek yönlü kargo trafiğinde taşınması için kargo uçağı satın almayı zorunlu kılmaktadır. Böylece gelir maksimizasyonu sağlanmaktadır.

Bu doğrultuda çalışmanın uygulama bölümünde havayolu kargo firması için kargo uçak modeli tercihi ele alınmıştır. Uygulama çalışması için gerekli olan veriler firmada çalışan üst düzey yöneticiler ve çalışanları ile farklı zamanlarda görüşmeler ile toplanmıştır. İlk aşamada, görüşmeler neticesinde ortaya çıkan kargo uçağı seçim kriterlerinin literatüre uygunluklarına bakılarak ve literatürden ekleme yapılarak 22 başlık oluşturulmuştur. Daha sonra her iki gruptan seçilen 7 uzmana bu 22 kriterin kargo uçak seçimi problemi için uygun olup olmadığı sorulmuştur. Tablo 7' de kriterin kargo uçağı seçimiyle ilgili olması durumunda "Evet", ilgili olmaması durumunda "Hayır" işaretlemeleri istenmiştir.

Tablo 7. Kargo Uçak Tipi Seçim Kriterleri Değerlendirme Anketi

\begin{tabular}{|l|l|l|l|}
\hline Sıra & Kargo Uçak Seçim Kriteri & Evet & Hayır \\
\hline 1 & Menzil - Range & & \\
\hline 2 & Menzile Göre Taşıma Kapasitesi & & \\
\hline 3 & İlk Alış Maliyeti & & \\
\hline 4 & Bakım Süreleri & & \\
\hline 5 & Bakım Maliyeti & & \\
\hline 6 & Tip Uyumluluğu - Filoya Uyum & & \\
\hline 7 & Taşıma Kapasitesi & & \\
\hline 8 & Operasyon Yapılacak Meydanlara Uyum & & \\
\hline 9 & Ekip Konfigürasyonu & & \\
\hline 10 & Finansman Olanağ1 & & \\
\hline 11 & Ekonomik Ömür & & \\
\hline
\end{tabular}


Akyurt, İ., Z., Kabaday1, N. / Journal of Yasar University, 2020, 15/57, 38-55

\begin{tabular}{|l|l|l|l|}
12 & Hurda Değeri & & \\
\hline 13 & Birim Yakıt Maliyeti & & \\
\hline 14 & Hacimsel Kapasite - Chargable Weight & & \\
\hline 15 & Ağırlık Kapasitesi - & & \\
\hline 16 & Uçak kapı büyüklüğü & & \\
\hline 17 & İklimlendirme Olanakları & & \\
\hline 18 & Gürültü Sınıfı & & \\
\hline 19 & Yedek Parça Maliyeti & & \\
\hline 20 & Ülkeye Uyum & & \\
\hline 21 & Takeoff weight - kalkış limiti & & \\
\hline 22 & Yükleme Kolaylığı & & \\
\hline
\end{tabular}

Bu aşamada sonrasında firmanın kargo uçağı seçimi ile ilgili olan 16 alt kriter 3 ana kriter başlığı altında toplanarak kargo uçak seçiminde kullanılacak olan kriter seti Tablo 8'deki gibi belirlenmiştir.

Tablo 8. Kargo Uçak Tipi Seçim Kriterleri

\begin{tabular}{|c|c|c|}
\hline Ana Kriter & Alt Kriter & Açıklama \\
\hline \multirow{6}{*}{$\begin{array}{l}\text { Maliyet } \\
\text { Kriterleri } \\
\quad(M)\end{array}$} & M1: İlk Alış Maliyeti & Uçağın para birimi olarak alış değeri \\
\hline & M2: Bakım Maliyeti & Yıllık ortalama bakıma ödenen para miktarı \\
\hline & M3: Hurda Değeri & Uçağın operasyonlardan çekildiği zamanki hurda değeri \\
\hline & M4: Yedek Parça Maliyeti & Y1llık ortalama yedek parçaya ödenen para miktarı \\
\hline & M5: Finansman Olanağı & Uçağın satın alınması esnasında sunulan finansal olanaklar \\
\hline & M6: Birim Yakıt Maliyeti & Saatte ortalama yakıt miktarı (ton/saat) \\
\hline \multirow{7}{*}{$\begin{array}{l}\text { Operasyonel } \\
\text { Uyumluluk } \\
\text { Kriterleri } \\
\text { (O) }\end{array}$} & O1: Menzil - Range & Dolu yakıt ile gidebileceği maksimum mesafe \\
\hline & O2: Gürültü Sınıfı & $\begin{array}{l}\text { Bazı havalimanlarına belli gürültü sınıfındaki uçaklar inemiyor. } \\
\text { (A,B,C ve D tipi gürültü sınıfları) }\end{array}$ \\
\hline & $\begin{array}{l}\text { O3: Tip Uyumluluğu - Filoya } \\
\text { Uyum }\end{array}$ & Havayolu işletmesinin mevcut uçak tiplerinden olup olmaması \\
\hline & $\begin{array}{l}\text { O4: Operasyon Yapılacak } \\
\text { Meydanlara Uyum }\end{array}$ & $\begin{array}{c}\text { Uçulacak noktanın teknik yeterliliği (pist, körük, rakım, } \\
\text { yaklaşma olanakları, taksi yolu vs) }\end{array}$ \\
\hline & O5: Yükleme kapasitesi & Uçağın ağırlık ve hacim olarak net kargo kapasitesi (ton ve m3) \\
\hline & O6: Bakım Süreleri & Uçağın belirlenmiş bakım tipine göre süreleri (saat veya gün) \\
\hline & O7: Uçak kapı büyüklüğü & Ana ve alt güverte kapı ölçüleri (cm) \\
\hline \multirow{3}{*}{$\begin{array}{l}\text { Zaman } \\
\text { Kriterleri } \\
\quad(Z)\end{array}$} & Z1: Uçuş hızı & Uçağın bir saatte uçabileceği mesafe (km/saat) \\
\hline & Z2: Teslim Zamanı & $\begin{array}{c}\text { Sipariş verildikten sonra ilk uçuşa başlayacağı ana kadar geçen } \\
\text { süre (ay) }\end{array}$ \\
\hline & Z3: Ekonomik Ömür & Operasyonlarda kullanılabileceği süre \\
\hline
\end{tabular}

\subsection{Kargo Uçak Tipi Seçim Kriter Ă̆ırlıklarının Bulanık AHP ile Belirlenmesi}

Kargo uçak seçiminde kullanılacak olan kriterlerin önem ağırlıklarının belirlenmesi amacıyla bulanık AHP yöntemi uygulanmıştır. Aşağıda bulanık AHP yönteminin uygulama adımları açıklanmıştır.

Adım 1: Bulanık ortalama karar matrisi oluşturulmuştur. Her bir karar vericinin ana kriterlerin önem derecelerini belirleyebilmek amacıyla Tablo 4'deki sözel ifadeler ile kriterin ikili karşılaştırmalı değerlendirmelerini gerçekleştirmesi talep edilmiştir. Daha sonra ilgili değerler üçgensel bulanık sayılara çevrilmiş ve karar matrislerinin geometrik ortalaması alınarak bulanık ortalama karar matrisi hesaplanmıştır. Tablo 9' da ana kriterlerin ikili karşılaştırmalarına ait bulanık ortalama karar matrisi yer almaktadır. Tablo 10, Tablo 11 ve Tablo 12'de sirasiyla maliyet, operasyonel uyumluluk ve zaman ana kriterlerinin alt kriterlerine ait bulanık ortalama karar matrisi yer almaktadır. 
Akyurt, İ., Z., Kabaday1, N. / Journal of Yasar University, 2020, 15/57, 38-55

Tablo 9. Ana Kriter Bulanık Ortalama Karar Matrisi

\begin{tabular}{|l|l|l|l|l|l|l|l|l|l|}
\hline & \multicolumn{4}{|c|}{$M$} & \multicolumn{3}{c|}{$O$} & \multicolumn{3}{c|}{$Z$} \\
\hline$M$ & 1,00 & 1,00 & 1,00 & 1,14 & 1,51 & 1,97 & 2,22 & 2,74 & 3,29 \\
\hline$O$ & 0,51 & 0,66 & 0,88 & 1,00 & 1,00 & 1,00 & 1,99 & 2,38 & 2,76 \\
\hline$Z$ & 0,30 & 0,37 & 0,45 & 0,36 & 0,42 & 0,50 & 1,00 & 1,00 & 1,00 \\
\hline
\end{tabular}

Tablo 10. Maliyet (M) Ana Kriterinin alt kriterleri için ortalama bulanık karar matrisi

\begin{tabular}{|c|c|c|c|c|c|c|c|c|c|c|c|c|c|c|c|c|c|c|}
\hline & \multicolumn{3}{|c|}{$M 1$} & \multicolumn{3}{c|}{$M 2$} & \multicolumn{3}{c|}{$M 3$} & \multicolumn{3}{c|}{$M 4$} & \multicolumn{3}{c|}{$M 5$} \\
\hline$M 1$ & 1,00 & 1,00 & 1,00 & 0,83 & 1,06 & 1,36 & 2,11 & 2,63 & 3,14 & 1,14 & 1,51 & 1,97 & 1,38 & 1,51 & 1,63 & 0,69 & 0,82 & 1,00 \\
\hline$M 2$ & 0,73 & 0,94 & 1,21 & 1,00 & 1,00 & 1,00 & 1,11 & 1,49 & 1,95 & 1,16 & 1,37 & 1,61 & 0,69 & 0,85 & 1,06 & 0,48 & 0,57 & 0,68 \\
\hline$M 3$ & 0,32 & 0,38 & 0,47 & 0,51 & 0,67 & 0,90 & 1,00 & 1,00 & 1,00 & 0,54 & 0,66 & 0,83 & 0,39 & 0,49 & 0,65 & 0,28 & 0,33 & 0,39 \\
\hline M4 & 0,51 & 0,66 & 0,88 & 0,62 & 0,73 & 0,86 & 1,21 & 1,51 & 1,86 & 1,00 & 1,00 & 1,00 & 0,57 & 0,77 & 1,06 & 0,42 & 0,51 & 0,63 \\
\hline$M 5$ & 0,61 & 0,66 & 0,73 & 0,94 & 1,17 & 1,44 & 1,55 & 2,03 & 2,56 & 0,94 & 1,29 & 1,74 & 1,00 & 1,00 & 1,00 & 0,73 & 0,85 & 1,00 \\
\hline M6 & 1,00 & 1,22 & 1,46 & 1,48 & 1,77 & 2,07 & 2,56 & 3,07 & 3,58 & 1,58 & 1,95 & 2,38 & 1,00 & 1,17 & 1,36 & 1,00 & 1,00 & 1,00 \\
\hline
\end{tabular}

Tablo 11. Operasyonel Uyumluluk (O) Kriterlerinin Alt Kriterleri için Ortalama Bulanık Karar Matrisi

\begin{tabular}{|c|c|c|c|c|c|c|c|c|c|c|c|c|c|c|c|c|c|c|c|c|c|}
\hline & \multicolumn{3}{|c|}{$O 1$} & \multicolumn{3}{|c|}{$O 2$} & \multicolumn{3}{|c|}{$O 3$} & \multicolumn{3}{|c|}{04} & \multicolumn{3}{|c|}{05} & \multicolumn{3}{|c|}{06} & \multicolumn{3}{|c|}{07} \\
\hline$O 1$ & 1 & 1 & 1 & 1,38 & 1,77 & 2,22 & 1 & 1,12 & 1,27 & 0,77 & 0,91 & 1,08 & 0,52 & 0,61 & 0,75 & 1,14 & 1,29 & 1,44 & 1 & 1,29 & 1,65 \\
\hline$O 2$ & 0,45 & 0,57 & 0,73 & 1 & 1 & 1 & 0,32 & 0,38 & 0,47 & 0,36 & 0,45 & 0,58 & 0,31 & 0,37 & 0,45 & 0,46 & 0,61 & 0,84 & 0,61 & 0,82 & 1,12 \\
\hline$O 3$ & 0,78 & 0,89 & 1 & 2,11 & 2,63 & 3,14 & 1 & 1 & 1 & 1 & 1,22 & 1,46 & 0,79 & 1 & 1,12 & 1,21 & 1,57 & 1,65 & 1,06 & 1,69 & 2,01 \\
\hline$O 4$ & 0,93 & 1,1 & 1,3 & 1,74 & 2,52 & 2,75 & 0,69 & 0,82 & 1 & 1 & 1 & 1 & 0,77 & 0,91 & 1,08 & 0,84 & 1,22 & 1,74 & 1,26 & 1,64 & 2,04 \\
\hline 05 & 1,34 & 1,64 & 1,92 & 2,21 & 3,34 & 3,26 & 0,89 & 1,06 & 1,27 & 1,21 & 1,43 & 1,65 & 1 & 1 & 1 & 1,34 & 1,81 & 2,35 & 1,82 & 2,34 & 2,85 \\
\hline 06 & 0,69 & 0,77 & 0,88 & 1,19 & 2,13 & 2,16 & 0,61 & 0,7 & 0,83 & 0,58 & 0,82 & 1,19 & 0,46 & 0,61 & 0,84 & 1 & 1 & 1 & 1,02 & 1,51 & 1,96 \\
\hline 07 & 0,83 & 1,06 & 1,36 & 0,89 & 1,43 & 1,64 & 0,5 & 0,67 & 0,94 & 0,55 & 0,67 & 0,85 & 0,42 & 0,52 & 0,66 & 0,51 & 0,7 & 0,99 & 1 & 1 & 1 \\
\hline
\end{tabular}

Tablo 12. Zaman Kriterlerinin (Z) Alt Kriterleri için Ortalama Bulanık Karar Matrisi

\begin{tabular}{|c|c|c|c|c|c|c|c|c|c|}
\hline & \multicolumn{3}{|c|}{$Z 1$} & \multicolumn{3}{c|}{$Z 2$} & \multicolumn{3}{c|}{$Z 3$} \\
\hline$Z 1$ & 1 & 1 & 1 & 0,69 & 0,94 & 1,28 & 0,48 & 0,62 & 0,82 \\
\hline$Z 2$ & 0,78 & 1,06 & 1,44 & 1 & 1 & 1 & 0,52 & 0,67 & 0,90 \\
\hline$Z 3$ & 1,23 & 1,60 & 2,07 & 1,11 & 1,49 & 1,92 & 1 & 1 & 1 \\
\hline
\end{tabular}

Adım 2: Bulanık sentetik mertebe değerleri hesaplanmıştır. Her bir kriter ana kriter ve alt kriter için bulanık sentetik mertebe değeri eşitlik (1) ile hesaplanır. Aşağıda "Maliyet" ana kriteri için bulanık sentetik mertebe değerinin hesaplanması gösterilmiştir.

$S_{M}=(4,36 ; 5,25 ; 6,26) \otimes(0,08 ; 0,09 ; 0,10)=(0,34 ; 0,47 ; 0,66)$

Tablo 13 'de ana kriter ve alt kriterleri için hesaplanan sentetik mertebe değerleri yer almaktadır.

Tablo 13. Ana Kriterler için Sentetik Mertebe Değerleri

\begin{tabular}{|c|c|}
\hline $\begin{array}{c}\text { Sentetik Mertebe } \\
\text { Dĕ̌eri }\end{array}$ & Bulanık Sayı Değeri \\
\hline$S_{M}$ & $(0,34 ; 0,47 ; 0,66)$ \\
\hline$S_{O}$ & $(0,27 ; 0,36 ; 0,49)$ \\
\hline$S_{Z}$ & $(0,13 ; 0,16 ; 0,20)$ \\
\hline
\end{tabular}

Tablo 14'de maliyet kriterinin alt kriterleri için hesaplanmış olan sentetik mertebe değerleri yer almaktadır. 
Tablo 14. Maliyet Kriterinin Alt Kriterleri için Sentetik Mertebe Değerleri

\begin{tabular}{|c|c|}
\hline $\begin{array}{c}\text { Sentetik Mertebe } \\
\text { Dĕ̌eri }\end{array}$ & Bulanık Sayı Dĕ̌geri \\
\hline $\mathrm{S}_{\mathrm{M} 1}$ & $(0,15 ; 0,21 ; 0,30)$ \\
\hline $\mathrm{S}_{\mathrm{M} 2}$ & $(0,11 ; 0,15 ; 0,22)$ \\
\hline $\mathrm{S}_{\mathrm{M} 3}$ & $(0,06 ; 0,09 ; 0,12)$ \\
\hline $\mathrm{S}_{\mathrm{M} 4}$ & $(0,09 ; 0,13 ; 0,18)$ \\
\hline $\mathrm{S}_{\mathrm{M} 5}$ & $(0,12 ; 0,17 ; 0,25)$ \\
\hline $\mathrm{S}_{\mathrm{M} 6}$ & $(0,18 ; 0,25 ; 0,35)$ \\
\hline
\end{tabular}

Tablo 15'de operasyonel uyumluluk kriterinin alt kriterleri için hesaplanan sentetik mertebe değerleri yer almaktadır.

Tablo 15. Operasyonel Uyumluluk Kriterinin Alt Kriterleri için Sentetik Mertebe Değerleri

\begin{tabular}{|c|c|}
\hline $\begin{array}{c}\text { Sentetik Mertebe } \\
\text { Değeri }\end{array}$ & Bulanık Sayı Dĕgeri \\
\hline $\mathrm{S}_{\mathrm{O} 1}$ & $(0,10 ; 0,14 ; 0,21)$ \\
\hline $\mathrm{S}_{\mathrm{O} 2}$ & $(0,05 ; 0,07 ; 0,11)$ \\
\hline $\mathrm{S}_{\mathrm{O} 3}$ & $(0,12 ; 0,17 ; 0,25)$ \\
\hline $\mathrm{S}_{\mathrm{O} 4}$ & $(0,11 ; 0,16 ; 0,24)$ \\
\hline $\mathrm{S}_{\mathrm{O} 5}$ & $(0,15 ; 0,22 ; 0,31)$ \\
\hline $\mathrm{S}_{\mathrm{O} 6}$ & $(0,08 ; 0,13 ; 0,19)$ \\
\hline $\mathrm{S}_{\mathrm{O} 7}$ & $(0,07 ; 0,11 ; 0,16)$ \\
\hline
\end{tabular}

Tablo 16'da zaman kriterinin alt kriterleri için hesaplanan sentetik mertebe değerleri yer almaktadır.

Tablo 16. Zaman Kriterinin Alt Kriterleri için Sentetik Mertebe Değerleri

\begin{tabular}{|c|c|}
\hline $\begin{array}{c}\text { Sentetik Mertebe } \\
\text { Değgeri }\end{array}$ & Bulanık Sayı Dĕ̌geri \\
\hline$S_{Z 1}$ & $(0,19 ; 0,27 ; 0,40)$ \\
\hline$S_{Z 2}$ & $(0,20 ; 0,29 ; 0,43)$ \\
\hline$S_{Z 3}$ & $(0,29 ; 0,44 ; 0,64)$ \\
\hline
\end{tabular}

Adım 3: Bulanık sentetik mertebe değerleri sıralanmıştır. Bu adımda Liou ve Wang (1992) tarafından geliştirilmiş olan "Toplam Entegral" yöntemi kullanılarak sentetik mertebe değerleri sıralanmıştır. Burada bir önceki aşamada hesaplanmış olan sentetik mertebe değerleri kullanılarak eşitlik (7) yardımıyla hesaplanmalar yapılmıştır. Buna göre iyimserlik indeksi $\alpha=0,8$ olmak üzere ana kriterlere ve alt kriterlere ait önem dereceleri aşağıdaki gibi hesaplanmıştır.

$I_{T}^{\alpha}\left(S_{M}\right)=\frac{1}{2}[0,8 * 0,66+0,47+(1-0,8) 0,34]=0,53$

$I_{T}^{\alpha}\left(S_{O}\right)=\frac{1}{2}[0,8 * 0,49+0,36+(1-0,8) 0,27]=0,40$

$I_{T}^{\alpha}\left(S_{Z}\right)=\frac{1}{2}[0,8 * 0,20+0,16+(1-0,8) 0,13]=0,18$

Yukarıda hesaplanmış olan değerlere göre ağırlık vektörü $W^{\prime}=(0,53 ; 0,40 ; 0,18)$ olarak belirlenmiştir. Bu değerler eşitlik (8) yardımıyla normalize edilerek ana kriterler için normalize edilmiş ağırlık değerleri Tablo 17 'deki gibi hesaplanmıştır.

Tablo 17. Ana Kriter Normalize Ağırlık Değerleri

\begin{tabular}{|c|c|c|}
\hline Kriter & Ağırlık & Normalize Ă̆ırlık \\
\hline Maliyet $(M)$ & 0,53 & 0,48 \\
\hline Operasyonel Uyumluluk $(O)$ & 0,40 & 0,36 \\
\hline $\operatorname{Zaman}(Z)$ & 0,18 & 0,16 \\
\hline
\end{tabular}

Her bir ana kritere ait alt kriterler için de aynı işlemler tekrar edilmiş ve Tablo 18'deki gibi normalize ağırlık değerleri hesaplanmıştır. 
Tablo 18: Bulanık AHP Yöntemi ile hesaplanan Kriter Ağırlık Değerleri

\begin{tabular}{|c|c|c|c|c|}
\hline Ana Kriter & Ăğlılı & Alt Kriter & Lokal Ağırlık & Genel Ağırlık \\
\hline \multirow{6}{*}{ Maliyet Kriterleri } & \multirow{6}{*}{0,48} & İlk Alış Maliyeti & 0,21 & 0,10 \\
\hline & & Bakım Maliyeti & 0,15 & 0,07 \\
\hline & & Hurda Değeri & 0,09 & 0,04 \\
\hline & & Yedek Parça Maliyeti & 0,13 & 0,06 \\
\hline & & Finansman Olanağı & 0,17 & 0,08 \\
\hline & & Birim Yakıt Maliyeti & 0,25 & 0,12 \\
\hline \multirow{7}{*}{ Operayonel Uyumluluk Kriterleri } & \multirow{7}{*}{0,36} & Menzil - Range & 0,14 & 0,05 \\
\hline & & Gürültü Sinıfı & 0,08 & 0,03 \\
\hline & & Tip Uyumluluğu - Filoya Uyum & 0,17 & 0,06 \\
\hline & & Operasyon Yapılacak Meydanlara Uyum & 0,16 & 0,06 \\
\hline & & Yükleme kapasitesi & 0,22 & 0,08 \\
\hline & & Bakım Süreleri & 0,13 & 0,05 \\
\hline & & Uçak kapı büyüklüğ̈̈ & 0,11 & 0,04 \\
\hline \multirow{3}{*}{ Zaman Kriterleri } & \multirow{3}{*}{0,16} & Uçuş hızl & 0,27 & 0,04 \\
\hline & & Teslim Zamanı & 0,29 & 0,05 \\
\hline & & Ekonomik Ömür & 0,44 & 0,07 \\
\hline
\end{tabular}

Adım 4: Çözümün geçerliliğinin kontrol edilmesi amacıyla tutarlılık oranı (CR) hesaplanmıştır. CR değerlerinin hesaplanabilmesi için öncelikle bulanık karar matrisi değerleri Eşitlik (9) ile durulaştırılmıştır. Daha sonra eşitlik (10) ve (11) yardımıyla CR değerleri hesaplanmıştır. Karar matrislerinin hesaplanan CR değerlerinin 0,10 'dan kü̧̈ük olması sebebiyle uygunluğu kabul edilmiştir.

Bulanık AHP yöntemi ile hesaplanmış olan kriter ağırlıklarına göre üç ana kriter arasında maliyet kriteri \%48'lik ağırlık değeri ile firma için kargo uçak seçimindeki en önemli kriter olarak belirlenmiştir. Operasyonel uyumluluk kriteri \%36 ağırlık değeri alarak maliyet kriterinden sonra ikinci en önemli ana kriter olarak belirlenmiştir. Kargo uçak seçimi kriterlerine alt kriterler detayında bakıldığında ise "birim yakıt maliyeti" en önemli alt kriterler olarak belirlenmiş̧ir. Bu kriterden sonra "ilk alış maliyeti", "finansman olanağı", "yükleme kapasitesi", "bakım maliyeti" ve "ekonomik ömür" de kargo uçağı seçiminde önemli kriterler olarak belirlenmiştir.

\subsection{Bulanık GIA Yöntemi ile Kargo Uçağı Seçimi}

Türk havayolu firması için en uygun kargo uçak modelinin seçimi için AHP ile belirlenmiş olan kriter ağırlıkları kullanılarak bulanık GIA yöntemi uygulanmıştır. Firma yetkileri tarafından belirlenmiş olan 4 geniş gövde uçak modeli firmanın farklı departmanlarında görev yapan 6 adet uzman tarafından değerlendirilmiş̧ir. Bulanık GIA yönteminin uygulama adımları aşağıdaki gibi özetlenebilir.

Adım 1: Bulanık ortalama gri ilişkiler matrisinin oluşturulması için Tablo 6 yardımıyla uzmanların sözel değerlendirilmeleri bulanık sayılara çevrilmiştir. Daha sonra ortalama karar matrisini oluşturmak amacıyla 6 adet uzmandan toplanan değerlendirme sonuçlarına geometrik ortalama yöntemi uygulanmıştır. Tablo 19 bulanık ortalama gri ilişkiler matrisi değerlerini göstermektedir.

Adım 2: Bulanık normalize gri ilişkiler matrisi oluşturulurken hedef değerin maksimizasyon veya minimizasyon olmasına göre iki farklı formül yardımıyla normalizasyon işlemi gerçekleştirilmiştir. Buna göre hedef değeri maksimizasyon olan "finansman olanağı", "menzil-range", "tip filoya uyumluluk", "operasyon yapilacak meydanlara uyum", taşıma kapasitesi”, "uçak kapı büyüklüğü”, "uçuş hızı", "ekonomik ömür” kriterleri eşitlik (24) yardımıyla normalize edilirken geriye kalan kriterler minimizasyon hedefli olduğu için eşitlik (25) yardımıyla normalize edilmiştir. Tablo 20 bulanık normalize gri ilişkiler matrisi değerlerini göstermektedir.

Adım 3: Bu adımda eşitlik (26) yardımıyla referans seri Tablo 21'deki gibi belirlenmiştir.

Adım 4: Referans seri değerleri ile karar matrisi değerleri arasındaki mesafeleri ifade eden $\tilde{\delta}_{i j}$ mesafeler matrisi eşitlik (27) yardımıyla Tablo 21 'deki gibi hesaplanmıştır.

Adım 5: Bulanık gri ilişkisel katsayı matrisi eşitlik (28) yardımıyla Tablo 22 'deki gibi hesaplanmıştır. $\xi$ katsayısı bu çalışmada da 0,5 olarak kabul edilmiştir.

Adım 6: Bulanık gri iliş̧kisel katsayı matrisi değerleri eşitlik (29) yardımıyla durulaştırılır. Tablo 23 'de durulaştırılmış gri ilişkisel katsayı matrisi yer almaktadır.

Adım 7: Kargo uçak modellerine ait gri ilişki derecelerinin hesaplanması için seçim kriterlerinin önem derecelerini ifade eden Tablo 18 'deki genel kriter ağırlık değerleri kullanılmıştır. Bu değerler ile gri ilişki katsayıları matrisi değerleri kullanılarak eşitlik (30) yardımıyla uçak modellerine ait gri ilişki dereceleri Tablo 24‘deki gibi hesaplanmıştı 
Akyurt, İ., Z., Kabadayı, N. / Journal of Yasar University, 2020, 15/57, 38-378

Tablo 19. Bulanık Ortalama Gri İlişkiler Matrisi

\begin{tabular}{|c|c|c|c|c|c|c|c|c|c|c|c|c|c|c|c|c|}
\hline Kargo Uçak Modeli & $M I$ & $M 2$ & M3 & M4 & M5 & M6 & $O 1$ & $O 2$ & $O 3$ & O4 & 05 & O6 & 07 & $Z 1$ & $\mathrm{Z} 2$ & $Z 3$ \\
\hline$B 777 F$ & $(0,6 ; 0,9 ; 1)$ & $(0,4 ; 0,7 ; 0,9)$ & $(0,40,6 ; 0,8)$ & $(0,3 ; 0,5 ; 0,8)$ & $(0,4 ; 0,7 ; 0,8)$ & $(0,3 ; 0,5 ; 0,8)$ & $(0,6 ; 0,9 ; 1)$ & $(0,3 ; 0,6 ; 0,8)$ & $(0,4 ; 0,7 ; 0,9)$ & $(0,6 ; 0,8 ; 1)$ & $(0,6 ; 0,8 ; 1)$ & $(0,4 ; 0,6 ; 0,8)$ & $(0,4 ; 0,7 ; 0,9)$ & $(0,3 ; 0,6 ; 0,8)$ & $(0,2,0,3 ; 0,6)$ & $(0,5 ; 0,8 ; 0,9)$ \\
\hline A330- $200 F$ & $(0,4 ; 0,6 ; 0,9)$ & $(0,3 ; 0,5,0,7)$ & $(0,3 ; 0,5 ; 0,8)$ & $(0,3 ; 0,5 ; 0,7)$ & $(0,4 ; 0,6 ; 0,9)$ & $(0,3 ; 0,5 ; 0,7)$ & $(0,4 ; 0,6 ; 0,9)$ & $(0,3 ; 0,5 ; 0,7)$ & $(0,5 ; 0,8 ; 0,9)$ & $(0,4 ; 0,6 ; 0,8)$ & $(0,4 ; 0,6 ; 0,8)$ & $(0,3 ; 0,5 ; 0,8)$ & $(0,3 ; 0,5 ; 0,7)$ & $(0,2 ; 0,4 ; 0,6)$ & $(0,2 ; 0,5 ; 0,7)$ & $(0,5 ; 0,7 ; 0,9)$ \\
\hline$B 747-400 F$ & ,9) & $(0,7 ; 1 ; 1)$ & $(0,2,0,4 ; 0,6)$ & $4 ; 0,6 ; 0,8)$ & $(0,4 ; 0,6 ; 0,8)$ & $(0,6 ; 0,8 ; 1)$ & $(0,3 ; 0,6 ; 0,8)$ & $(0,3 ; 0,5 ; 0,7)$ & $(0,2 ; 0,4 ; 0,6)$ & $(0,4 ; 0,6 ; 0,8)$ & $(0,6 ; 0,9 ; 1)$ & $(0,5 ; 0,8 ; 1)$ & $(0,5 ; 0,8,0,9)$ & $(0,3 ; 0,5 ; 0,7)$ & $(0,3 ; 0,5 ; 0,7)$ & $(0,3 ; 0,5 ; 0,7)$ \\
\hline$A 310-300 \mathrm{~F}$ & $(0,1 ; 0,3 ; 0,5)$ & $(0,5 ; 0,8 ; 0,9)$ & $(0,1 ; 0,2 ; 0,5)$ & $(0,3 ; 0,5 ; 0,7)$ & $(0,2 ; 0,5 ; 0,7)$ & $(0,4 ; 0,6 ; 0,8)$ & $(0,2 ; 0,5 ; 0,7)$ & $(0,1 ; 0,3 ; 0,6)$ & $(0,4 ; 0,7 ; 0,9)$ & $(0,4 ; 0,7 ; 0,9)$ & $(0,2 ; 0,4 ; 0,7)$ & $(0,5 ; 0,8 ; 0,9)$ & $(0,3 ; 0,5 ; 0,7)$ & $(0,1 ; 0,3 ; 0,6)$ & $(0,2 ; 0,5 ; 0,7)$ & $(0,2 ; 0,3 ; 0,5)$ \\
\hline
\end{tabular}

Tablo 20. Bulanık Normalize Gri İlişkiler Matrisi

\begin{tabular}{|c|c|c|c|c|c|c|c|c|c|c|c|c|c|c|c|c|}
\hline $\begin{array}{c}\text { Kargo Uçak } \\
\text { Modeli }\end{array}$ & $M 1$ & $M 2$ & M3 & M4 & M5 & M6 & $O 1$ & $O 2$ & O3 & O4 & O5 & O6 & 07 & $Z 1$ & $Z 2$ & $Z 3$ \\
\hline$B 777 F$ & $\begin{array}{c}(0,10 ; \\
0,11 ; 0,10)\end{array}$ & $\begin{array}{c}(0,33 ; 0,45 ; \\
0,72)\end{array}$ & $\begin{array}{c}(0,13 ; 0,17 ; \\
0,29)\end{array}$ & $\begin{array}{c}(0,33 ; 0,46 ; \\
0,75)\end{array}$ & $\begin{array}{c}(0,55 ; 0,83 ; \\
1)\end{array}$ & $\begin{array}{c}(0,40 ; 0,60 ; \\
1)\end{array}$ & $\begin{array}{c}(0,63 ; 0,92 ; \\
1)\end{array}$ & $\begin{array}{c}(0,13 ; 0,17 \\
0,30)\end{array}$ & $\begin{array}{l}(0,60 ; 0,88 ; \\
1)\end{array}$ & $\begin{array}{c}(0,60 ; 0,88 ; \\
1)\end{array}$ & $\begin{array}{c}(0,60 ; 0,88 ; \\
1)\end{array}$ & $\begin{array}{c}(0,41 ; 0,57 \\
0,95)\end{array}$ & $\begin{array}{c}(0,48 ; 0,74 ; \\
1)\end{array}$ & $\begin{array}{c}(0,43 ; 0,74 ; \\
1)\end{array}$ & $\begin{array}{c}(0,31 ; 0,55 \\
1)\end{array}$ & $\begin{array}{l}(0,56 ; 0,83 ; \\
1)\end{array}$ \\
\hline A330- $200 F$ & $\begin{array}{c}(0,12 ; 0,16 ; \\
0,25)\end{array}$ & $\begin{array}{c}(0,43 ; 0,60 ; \\
1)\end{array}$ & $\begin{array}{c}(0,13 ; 0,18 ; \\
0,30)\end{array}$ & $\begin{array}{c}(0,38 ; 0,55 ; \\
1)\end{array}$ & $\begin{array}{c}(0,47 ; 0,74 ; \\
1)\end{array}$ & $\begin{array}{c}(0,43 ; 0,60 ; \\
1)\end{array}$ & $\begin{array}{c}(0,40 ; 0,63 ; \\
0,85)\end{array}$ & $\begin{array}{c}(0,14 ; 0,18 ; \\
0,33)\end{array}$ & $\begin{array}{c}(0,42 ; 0,66 ; \\
0,84)\end{array}$ & $\begin{array}{c}(0,39 ; 0,62 ; \\
0,84)\end{array}$ & $\begin{array}{c}(0,39 ; 0,61 ; \\
0,84)\end{array}$ & $\begin{array}{c}(0,44 ; 0,62 ; \\
1)\end{array}$ & $\begin{array}{c}0,33 ; 0,56 ; \\
0,78)\end{array}$ & $\begin{array}{c}0,26 ; 0,53 ; \\
0,81)\end{array}$ & $\begin{array}{c}(0,27 ; 0,40 \\
0,79)\end{array}$ & $\begin{array}{c}(0,52 ; 0,79 ; \\
1)\end{array}$ \\
\hline$B 747-400 F$ & $\begin{array}{c}(0,11 ; 0,12 ; 0 \\
, 18)\end{array}$ & $\begin{array}{c}(0,30 ; 0,31 ; \\
0,45)\end{array}$ & $\begin{array}{c}(0,17 ; 0,27 ; \\
0,46)\end{array}$ & $\begin{array}{c}(0,32 ; 0,40 ; \\
0,60)\end{array}$ & $\begin{array}{c}(0,47 ; 0,74 ; \\
0,94)\end{array}$ & $\begin{array}{c}(0,32 ; 0,36 ; \\
0,53)\end{array}$ & $\begin{array}{c}(0,33 ; 0,58 \\
0,78)\end{array}$ & $\begin{array}{c}(0,14 ; 0,18 \\
0,33)\end{array}$ & $\begin{array}{c}(0,40 ; 0,66 ; \\
0,81)\end{array}$ & $\begin{array}{c}(0,63 ; 0,92 ; \\
1)\end{array}$ & $\begin{array}{c}(0,63 ; 0,92 ; \\
1)\end{array}$ & $\begin{array}{c}(0,35 ; 0,42 ; \\
0,63)\end{array}$ & $\begin{array}{c}(0,59 ; 0,88 ; \\
1)\end{array}$ & $\begin{array}{c}(0,38 ; 0,69 ; \\
0,94)\end{array}$ & $\begin{array}{c}(0,25 ; 0,34 ; \\
0,61)\end{array}$ & $\begin{array}{c}(0,28 ; 0,51 ; \\
0,74)\end{array}$ \\
\hline$A 310-300 \mathrm{~F}$ & $\begin{array}{c}(0,19 ; 0,34 ; 1 \\
)\end{array}$ & $\begin{array}{c}(0,33 ; 0,40 ; \\
0,60)\end{array}$ & $\begin{array}{c}(0,21 ; 0,48 ; \\
1)\end{array}$ & $\begin{array}{c}(0,37 ; 0,50 ; \\
0,79)\end{array}$ & $\begin{array}{c}(0,27 ; 0,54 ; \\
0,80)\end{array}$ & $\begin{array}{c}(0,39 ; 0,51 ; \\
0,86)\end{array}$ & $\begin{array}{c}(0,23 ; 0,46 ; \\
0,68)\end{array}$ & $\begin{array}{c}(0,18 ; 0,30 ; \\
1)\end{array}$ & $\begin{array}{c}(0,46 ; 0,70 ; \\
0,89)\end{array}$ & $\begin{array}{c}(0,19 ; 0,44 ; \\
0,68)\end{array}$ & $\begin{array}{c}(0,19 ; 0,44 ; \\
0,68)\end{array}$ & $\begin{array}{c}(0,37 ; 0,44 ; \\
0,67)\end{array}$ & $\begin{array}{c}(0,28 ; 0,51 ; \\
0,74)\end{array}$ & $\begin{array}{c}(0,13 ; 0,43 ; \\
0,72)\end{array}$ & $\begin{array}{c}(0,27 ; 0,40 ; \\
0,79)\end{array}$ & $\begin{array}{c}(0,17 ; 0,32 ; \\
0,59)\end{array}$ \\
\hline
\end{tabular}


Akyurt, İ., Z., Kabaday1, N. / Journal of Yasar University, 2020, 15/57, 38-55

Tablo 21. Referans Seri ve Mesafeler Matrisi

\begin{tabular}{|c|c|c|c|c|c|c|c|c|c|c|c|c|c|c|c|c|}
\hline $\begin{array}{c}\text { Kargo Uçak } \\
\text { Modeli }\end{array}$ & $M 1$ & $M 2$ & M3 & M4 & M5 & M6 & $O 1$ & $O 2$ & $O 3$ & 04 & O5 & O6 & 07 & ZI & Z2 & Z3 \\
\hline Referans Seri & $\begin{array}{c}(0,19 ; 0,34 \\
1)\end{array}$ & $(0,43 ; 0,6 ; 1)$ & $\begin{array}{c}(0,21 ; 0,48 \\
1)\end{array}$ & $\begin{array}{c}(0,38 ; 0,55 \\
1)\end{array}$ & $\begin{array}{c}(0,55 ; 0,83 ; \\
1)\end{array}$ & $(0,43 ; 0,6 ; 1)$ & $\begin{array}{c}(0,63 ; 0,92 ; \\
1)\end{array}$ & $\begin{array}{c}(0,18 ; 0,30 ; \\
1)\end{array}$ & $\begin{array}{c}(0,56 ; 0,86 \\
1)\end{array}$ & $(0,6 ; 0,88 ; 1)$ & $\begin{array}{c}(0,63 ; 0,92 ; \\
1)\end{array}$ & $\begin{array}{c}(0,44 ; 0,62 ; \\
1)\end{array}$ & $\begin{array}{c}(0,59 ; 0,88 \\
1)\end{array}$ & $\begin{array}{c}(0,43 ; 0,74 ; \\
1)\end{array}$ & $\begin{array}{c}(0,31 ; 0,55 \\
1)\end{array}$ & $\begin{array}{l}(0,56 ; 0,83 ; \\
1)\end{array}$ \\
\hline$B 777 F$ & $\begin{array}{c}(0,09 ; 0,23 ; \\
0,83) \\
\end{array}$ & $\begin{array}{c}0,1 ; 0,15 ; 0, \\
28)\end{array}$ & $\begin{array}{c}(0,08 ; 0,31 ; \\
0,71) \\
\end{array}$ & $\begin{array}{c}(0,04 ; 0,08 ; \\
0,25)\end{array}$ & $(0 ; 0 ; 0,0)$ & $(0,03 ; 0 ; 0)$ & $(0 ; 0 ; 0)$ & $\begin{array}{c}0,05 ; 0,13 ; \\
0,70)\end{array}$ & $\begin{array}{c}(0,11 ; 0,14 ; \\
0)\end{array}$ & $(0 ; 0 ; 0)$ & $\begin{array}{c}(0,04 ; 0,04 ; \\
0)\end{array}$ & $\begin{array}{c}(0,04 ; 0,04 ; \\
0,05)\end{array}$ & $\begin{array}{c}(0,11 ; 0,14 \\
0)\end{array}$ & $(0 ; 0 ; 0)$ & $(0 ; 0 ; 0)$ & $(0 ; 0 ; 0)$ \\
\hline A330-200F & $\begin{array}{c}(0,07 ; 0,18 ; \\
0,75) \\
\end{array}$ & $(0,0,0)$ & $\begin{array}{c}(0,08 ; 0,30 ; \\
0,7)\end{array}$ & $(0 ; 0 ; 0)$ & $\begin{array}{c}(0,08 ; 0,10 ; \\
0)\end{array}$ & $(0 ; 0 ; 0)$ & $\begin{array}{c}(0 ; 23 ; 0,29 ; \\
0,15) \\
\end{array}$ & $\begin{array}{c}(0,04 ; 0,12 ; \\
0,67) \\
\end{array}$ & $(0 ; 0 ; 0)$ & $\begin{array}{c}(0,18 ; 0,22 ; \\
0,16) \\
\end{array}$ & $\begin{array}{c}(0,25 ; 0,31 ; \\
0,16) \\
\end{array}$ & $(0 ; 0 ; 0)$ & $\begin{array}{c}(0,26 ; 0,32 ; \\
0,22) \\
\end{array}$ & $\begin{array}{c}(0,17 ; 0,21 ; \\
0,19)\end{array}$ & $\begin{array}{c}(0,05 ; 0,15 ; \\
0,21) \\
\end{array}$ & $\begin{array}{c}(0,04 ; 0,05 ; \\
0)\end{array}$ \\
\hline$B 747-400 F$ & $\begin{array}{c}0,08 ; 0,22 ; \\
0,82)\end{array}$ & $\begin{array}{c}(0,13 ; 0,29 ; \\
0,55)\end{array}$ & $\begin{array}{c}(0,04 ; 0,21 ; \\
0,54)\end{array}$ & $\begin{array}{c}(0,06 ; 0,15 ; \\
0,4)\end{array}$ & $\begin{array}{c}(0,08 ; 0,10 ; \\
0,06)\end{array}$ & $\begin{array}{c}0,11 ; 0,24 ; \\
0,47)\end{array}$ & $\begin{array}{c}(0,30 ; 0,33 ; \\
0,22)\end{array}$ & $\begin{array}{c}0,04 ; 0,12 ; \\
0,67)\end{array}$ & $\begin{array}{c}(0,4 ; 0,45 ; 0, \\
35)\end{array}$ & $\begin{array}{c}0,19 ; 0,22 ; \\
0,19)\end{array}$ & $(0 ; 0 ; 0)$ & $\begin{array}{c}0,09 ; 0,19 ; \\
0,38)\end{array}$ & $(0 ; 0 ; 0)$ & $\begin{array}{c}(0,04 ; 0,05 ; \\
0,06)\end{array}$ & $\begin{array}{c}(0,06 ; 0,21 ; \\
0,39)\end{array}$ & $\begin{array}{c}(0,28 ; 0,32 ; \\
0,26)\end{array}$ \\
\hline$A 310-300 \mathrm{~F}$ & $(0 ; 0 ; 0)$ & $\begin{array}{c}(0,1 ; 0,2 ; 0,4 \\
)\end{array}$ & $(0 ; 0 ; 0)$ & $\begin{array}{c}(0,01 ; 0,05 ; \\
0,21)\end{array}$ & $\begin{array}{c}(0,27 ; 0,29 ; \\
0,20)\end{array}$ & $\begin{array}{c}(0,04 ; 0,09 ; \\
0,14)\end{array}$ & $\begin{array}{c}(0,40 ; 0,46 ; \\
0,32)\end{array}$ & $(0 ; 0 ; 0)$ & $\begin{array}{c}(0,09 ; 0,14 \\
0,02)\end{array}$ & $\begin{array}{c}(0,14 ; 0,18 ; \\
0,11)\end{array}$ & $\begin{array}{c}(0,44 ; 0,48 ; \\
0,32)\end{array}$ & $\begin{array}{c}(0,07 ; 0,17 ; \\
0,33)\end{array}$ & $\begin{array}{c}(031 ; 0,37 ; 0 \\
, 26)\end{array}$ & $\begin{array}{c}(0,3 ; 0,32 ; 0, \\
28)\end{array}$ & $\begin{array}{c}(0,05 ; 0,15 ; \\
0,21)\end{array}$ & $\begin{array}{c}(0,39 ; 0,51 ; \\
0,41)\end{array}$ \\
\hline
\end{tabular}

Tablo 22. Bulanık Gri İlişkiler Katsayı Matrisi

\begin{tabular}{|c|c|c|c|c|c|c|c|c|c|c|c|c|c|c|c|c|}
\hline $\begin{array}{c}\text { Kargo Uçak } \\
\text { Modeli }\end{array}$ & $M 1$ & $M 2$ & M3 & M4 & M5 & M6 & $O I$ & $\mathrm{O} 2$ & O3 & 04 & O5 & 06 & 07 & $Z 1$ & $Z 2$ & Z3 \\
\hline B777F & $\begin{array}{c}(0,83 ; 0,65 ; \\
0,33) \\
\end{array}$ & $\begin{array}{c}(0,73 ; 0,65 ; \\
0,50) \\
\end{array}$ & $\begin{array}{c}(0,81 ; 0,54 \\
0,33)\end{array}$ & $\begin{array}{c}(0,83 ; 0,70 ; \\
0,44)\end{array}$ & $(1 ; 1 ; 1)$ & $(0,89 ; 1 ; 1)$ & $(1 ; 1 ; 1)$ & $\begin{array}{c}(0,88 ; 0,73 \\
0,33)\end{array}$ & $\begin{array}{c}(0,68 ; 0,63 ; \\
1)\end{array}$ & $(1 ; 1 ; 1)$ & $\begin{array}{c}(0,87 ; 0,85 ; \\
1)\end{array}$ & $\begin{array}{c}(0,84 ; 0,81 ; \\
0,80)\end{array}$ & $\begin{array}{c}(0,63 ; 0,57 \\
1)\end{array}$ & $(1 ; 1 ; 1)$ & $(1 ; 1 ; 1)$ & $(1 ; 1 ; 1)$ \\
\hline $\mathrm{A} 330-200 \mathrm{~F}$ & $\begin{array}{c}(0,86 ; 0,69 ; \\
0,36) \\
\end{array}$ & $(1 ; 1 ; 1)$ & $\begin{array}{c}(0,82 ; 0,55 ; \\
0,34) \\
\end{array}$ & $(1 ; 1 ; 1)$ & $\begin{array}{c}(0,65 ; 0,60 ; \\
1)\end{array}$ & $(1 ; 1 ; 1)$ & $\begin{array}{c}(0,50 ; 0,44 ; \\
0,60) \\
\end{array}$ & $\begin{array}{c}(0,90 ; 0,75 ; \\
0,34)\end{array}$ & $(1 ; 1 ; 1)$ & $\begin{array}{c}(0,38 ; 0,33 ; \\
0,41) \\
\end{array}$ & $\begin{array}{c}(0,50 ; 0,44 ; \\
0,60)\end{array}$ & $(1 ; 1 ; 1)$ & $\begin{array}{c}(0,42 ; 0,36 ; \\
0,45)\end{array}$ & $\begin{array}{c}(0,48 ; 0,43 ; \\
0,45)\end{array}$ & $\begin{array}{c}(0,81 ; 0,56 ; \\
0,48)\end{array}$ & $\begin{array}{l}(0,87 ; 0,85 ; \\
1)\end{array}$ \\
\hline B747-400F & $\begin{array}{c}(0,84 ; 0,65 ; \\
0,34)\end{array}$ & $\begin{array}{c}(0,68 ; 0,49 ; \\
0,33)\end{array}$ & $\begin{array}{c}0,89 ; 0,63 ; \\
0,40)\end{array}$ & $\begin{array}{c}0,78 ; 0,58 \\
0,33)\end{array}$ & $\begin{array}{c}(0,65 ; 0,60 ; \\
0,71) \\
\end{array}$ & $\begin{array}{c}(0,68 ; 0,50 ; \\
0,33)\end{array}$ & $\begin{array}{c}(0,43 ; 0,41 ; \\
0,51)\end{array}$ & $\begin{array}{c}(0,90 ; 0,75 \\
0,34) \\
\end{array}$ & $\begin{array}{c}(0,36 ; 0,33 ; \\
0,40)\end{array}$ & $\begin{array}{c}(0,36 ; 0,33 ; \\
0,36)\end{array}$ & $(1 ; 1 ; 1)$ & $\begin{array}{c}(0,67 ; 0,49 ; \\
0,33)\end{array}$ & $(1 ; 1 ; 1)$ & $\begin{array}{c}0,79 ; 0,75 \\
0,71) \\
\end{array}$ & $\begin{array}{c}0,75 ; 0,48 \\
0,33)\end{array}$ & $\begin{array}{c}(0,48 ; 0,44 ; \\
0,50)\end{array}$ \\
\hline $\mathrm{A} 310-300 \mathrm{~F}$ & $(1 ; 1 ; 1)$ & $\begin{array}{c}(0,74 ; 0,58 ; \\
0,41)\end{array}$ & $(1 ; 1 ; 1)$ & $\begin{array}{c}(0,96 ; 0,81 ; \\
0,49)\end{array}$ & $\begin{array}{c}(0,35 ; 0,33 ; \\
0,43)\end{array}$ & $\begin{array}{c}(0,86 ; 0,73 ; \\
0,62)\end{array}$ & $\begin{array}{c}(0,36 ; 0,33 ; \\
0,42)\end{array}$ & $(1 ; 1 ; 1)$ & $\begin{array}{c}(0,71 ; 0,63 ; \\
0,93)\end{array}$ & $\begin{array}{c}(0,44 ; 0,38 ; \\
0,51)\end{array}$ & $\begin{array}{c}(0,35 ; 0,33 \\
0,43)\end{array}$ & $\begin{array}{c}(0,72 ; 0,52 ; \\
0,36)\end{array}$ & $\begin{array}{c}(0,37 ; 0,33 ; \\
0,42)\end{array}$ & $\begin{array}{c}(0,35 ; 0,33 ; \\
0,37)\end{array}$ & $\begin{array}{c}(0,81 ; 0,56 \\
0,48)\end{array}$ & $\begin{array}{c}(0,40 ; 0,33 ; \\
0,38)\end{array}$ \\
\hline
\end{tabular}


Akyurt, İ., Z., Kabaday1, N. / Journal of Yasar University, 2020, 15/57, 38-378

Tablo 23. Durulaştırılmış Gri Ilişkisel Katsayı Matrisi

\begin{tabular}{|c|c|c|c|c|c|c|c|c|c|c|c|c|c|c|c|c|}
\hline Kargo Uçak Modeli & M1 & M2 & M3 & M4 & M5 & M6 & O1 & O2 & O3 & O4 & O5 & O6 & O7 & Z1 & Z2 & Z3 \\
\hline B777F & 0,61 & 0,63 & 0,55 & 0,67 & 1,00 & 0,97 & 1,00 & 0,67 & 0,73 & 1,00 & 0,89 & 0,81 & 0,69 & 1,00 & 1,00 & 1,00 \\
\hline A330- $200 F$ & 0,65 & 1,00 & 0,56 & 1,00 & 0,71 & 1,00 & 0,49 & 0,69 & 1,00 & 0,37 & 0,49 & 1,00 & 0,40 & 0,45 & 0,60 & 0,89 \\
\hline$B 747-400 F$ & 0,62 & 0,50 & 0,64 & 0,57 & 0,64 & 0,50 & 0,44 & 0,69 & 0,36 & 0,35 & 1,00 & 0,50 & 1,00 & 0,75 & 0,51 & 0,46 \\
\hline$A 310-300 F$ & 1,00 & 0,58 & 1,00 & 0,77 & 0,36 & 0,74 & 0,36 & 1,00 & 0,72 & 0,43 & 0,36 & 0,53 & 0,36 & 0,35 & 0,60 & 0,36 \\
\hline
\end{tabular}

Tablo 24. Kargo Uçak Modellerine Ait Gri Ilişki Dereceleri

\begin{tabular}{|c|c|}
\hline $\begin{array}{c}\text { Kargo Uçak } \\
\text { Modeli }\end{array}$ & $\begin{array}{c}\text { Gri İlişki } \\
\text { Dereceleri }\end{array}$ \\
\hline B777F & 0,84 \\
\hline A330-200F & 0,74 \\
\hline B747-400F & 0,59 \\
\hline A310-300 F & 0,60 \\
\hline
\end{tabular}

Bulanık GIA yöntemi ile yapılan hesaplamalar sonucunda B777F model kargo uçağının firma için en uygun uçak modeli olduğu anlaşılmıştır. Bu analiz sonucuna göre, sırasıyla A330-200F, A310-300F ve B747-400F model kargo uçakları firma için B777F model kargo uçağından sonra uygun olan uçak modelleridir.

\section{Sonuç ve Tartışma}

Günümüzde küreselleşme ve e-ticaret kapasitesindeki hacim artışı ile birlikte kargo taşımacılığg firmalar için stratejik bir unsur haline gelmiştir. Ayrıca, son yıllardaki yolcu bilet fiyatlarının düşmesi ve yolcu taşımacılığındaki kar marjlarının azalması havayolu şirketlerini ilave gelir kaynaklarını araştırmaya yöneltmektedir. Bundan 10 yıl önce yolcu biletlerinden elde edilen gelir toplam gelirlerin yaklaşık \%78'ini oluştururken kargo taşımacılığından elde edilen gelir \%10’unu oluşturmaktayd1. Günümüzde bu oranlar değişmiş ve kargo taşımacılığından elde edilen gelir artarken yolcu taşımacılığından elde edilen gelir azaltmıştır. Daha önce kargo taşımacılığından elde edilen gelir, toplam gelirlerin \% 10 'u iken günümüzde \%14'e yükselmiştir. Önümüzdeki yıllarda bu yükselişin devam etmesi ve bu oranın \%20 civarına ulaşması beklenmektedir. Ayrıca yolcu uçaklarının önceliği insan taşımak olduğu için rotalarının çift yönlü olması gerekmektedir. Bu durum yük taşımacılığında maliyet ve zaman kaybına neden olabilmektedir. Bu sebeplerden ötürü, havayolu şirketleri, sadece kargo taşıyan, kargo uçağı satın almaktadır ve en uygun kargo uçağının seçilmesi firmaların rekabet gücü açısından kritik öneme sahiptir.

Bu çalışmada bir Türk havayolu firması için kargo uçağı seçimi problemi ele alınmıştır. Problemin çözümü için daha önce uçak seçimi probleminin çözümü için daha önce literatürde kullanılmamış olan bütünleşik bir yöntem tercih edilmiştir. Bu yöntemde uçak seçimi kriter ağırlıkları bulanık AHP yöntemi ile belirlenmiş ve daha sonra bu ağırlıklar kullanılarak bulanık GIA yöntemi ile en uygun kargo uçak modeli belirlenmiştir. Ulutaş vd. (2018) tarafından da belirtildiği gibi bulanık GIA ile ilgili Türkçe yayınların kısıtlı sayıda olması nedeniyle bu çalışmanın yerel literatüre katkısı olacağı düşünülmektedir. Kargo uçağı seçim probleminde alınacak kararların havayolu kargo firmaları açısından rekabet avantajı kazandırabilecek nitelikte olması bu kararların stratejik kararlar olarak ele alınmasını gerektirmektedir. Firmaların stratejik karar süreçlerinde farklı kademelerden yöneticilerin bilgi ve tecrübelerinin problemin çözümüne katılması oldukça önemlidir. Bu açıdan bu çalışmada kullanılmış olan bulanık AHP ve bulanık GIA yöntemleri kargo uçak seçimi probleminin çözümünde iyi bir performans göstermiştir. Çalışmanın uygulama bölümünde ele alınan problemin sonuçları firma yetkilileri ile paylaşılmış ve çözümün gerçek hayat koşullarına uygunluğu sorgulanmıştır. Firma yetkililerinden alınmış olan geri bildirim sonucunda uygulanmış olan yöntemlerin gerçek hayat koşullarına uygun sonuçlar üretmiş olduğu kanıtlanmıştır.

Bu çalışmanın uygulama bölümünde ele alınmış olan kargo uçağı seçimi kriterleri firma yetkilileri ile yapılmış olan görüşme ve anketler ile belirlenmiştir. Bir ön çalışma ile belirlenmiş olan bu kapsamlı kriter setinin ileride yapılacak olan kargo uçağı seçimi ile ilgili çalışmalara yön gösterici olacağı tahmin edilmektedir. Çalışmada kullanılmış olan ÇKKV yöntemlerinin kolay uygulanabilir olması, uzmanların bilgi ve tecrübelerinin sözel değerlendirmeler ile yöntemlere dahil edilebilmesi sayesinde gerçek hayatta uygulanabilme potansiyeli yüksektir. Çalışmanın ileriki aşamalarında farklı yöntemler kullanılarak bu kriter ağırlıklarıyla aynı uçak tipi seçimi problemi üzerine çalışılarak yöntemlerin performansları karşılaştırılabilir. 
Ahmadi, A., Gupta, S., Karim, R., \& Kumar, U. 2010. "Selection of maintenance strategy for aircraft systems using multicriteria decision making methodologies." International Journal of Reliability, Quality and Safety Engineering, 17(03), 223-243.

Avci, A. G. S., Şahin, Y., \& Çelik, B. 2017. “Gri İlişkisel Analiz Yöntemi İle En İyi Konaklama Yeri Seçimi.” 7th International Conference of Strategic Research on Social Science and Education, 187-196

Bhadra, D. 2003. "Choice of aircraft fleets in the US NAS: findings from a multinomial logit analysis." In AIAA's 3rd Annual Aviation Technology, Integration, and Operations (ATIO) Forum(p. 6767).

Bülbül, M. E. 2014. Inovasyon performansı değerlendirme sürecinde AHS ve GìA bütünleşik yaklaşımı: süt ürünleri sektöründe bir uygulama (Master's thesis, ESOGÜ, Sosyal Bilimler Enstitüsü).

Chai J., Liu J.N.K. and Ngai E.W.T., 2013. "Application of decision making techniques in supplier selection: A Systematic review of literature," Expert Systems with Applications, vol. 40, pp. 3872-3885.

Chan, F. T., Kumar, N., Tiwari, M. K., Lau, H. C., \& Choy, K. L. 2008. "Global supplier selection: a fuzzy-AHP approach.” International Journal of production research, 46(14), 3825-3857.

Chang, D. Y. 1996. "Applications of the extent analysis method on fuzzy AHP." European journal of operational research, 95(3), 649-655.

Deveci, M., Demirel, N. Ç., \& Ahmetoğlu, E. 2017. “Airline new route selection based on interval type-2 fuzzy MCDM: A case study of new route between Turkey-North American region destinations." Journal of Air Transport Management, 59, 83-99.

Dožić, S., \& Kalić, M. 2014. “An AHP approach to aircraft selection process.” Transportation Research Procedia, 3 , 165-174.

Dožić, S., \& Kalić, M. 2015. "Comparison of two MCDM methodologies in aircraft type selection problem.” Transportation Research Procedia, 10, 910-919.

Dožić, S., Lutovac, T., \& Kalić, M. 2018. "Fuzzy AHP approach to passenger aircraft type selection.” Journal of Air Transport Management, 68, 165-175.

Ecer, F. 2013. “Türkiye'deki özel bankaların finansal performanslarının karşılaştırılması: 2008-2011 dönemi.” Abant İzet Baysal Üniversitesi Sosyal Bilimler Enstitüsü Dergisi.

Gomes, L. F. A. M., Mattos Fernandes, J. E., \& Mello, J. C. C. 2014. “A fuzzy stochastic approach to the multicriteria selection of an aircraft for regional chartering." Journal of Advanced Transportation, 48(3), 223-237.

Goyal, S., \& Grover, S. 2012. "Applying fuzzy grey relational analysis for ranking the advanced manufacturing systems." Grey Systems: Theory and Application, 2(2), 284-298.

Göksu, A., \& Güngör, İ. 2008. "Bulanik Analitik Hiyerarşik Proses Ve Üniversite Tercih Siralamasinda Uygulanmas1." Süleyman Demirel Üniversitesi İktisadi ve İdari Bilimler Fakültesi Dergisi, 13(3), 1-26.

Gumus, A., Yayla, A., Çelik, E., \& Yildiz, A. 2013. “A combined fuzzy-AHP and fuzzy-GRA methodology for hydrogen energy storage method selection in Turkey.” Energies, 6(6), 3017-3032.

Harasani, W. I. 2006. "Evaluation and Selection of a Fleet of Aircraft for a Local Airline.” Journal of King. Abdulaziz University: Engineering Sciences, 17(2), 3-16.

Hashemi, S. H., Karimi, A., \& Tavana, M. 2015. "An integrated green supplier selection approach with analytic network process and improved Grey relational analysis.” International Journal of Production Economics, 159, 178-191.

Heo, E., Kim, J., \& Boo, K. J. 2010. “Analysis of the assessment factors for renewable energy dissemination program evaluation using fuzzy AHP." Renewable and Sustainable Energy Reviews, 14(8), 2214-2220.

Kabir, G. 2012. "Multiple criteria inventory classification under fuzzy environment." International Journal of Fuzzy System Applications (IJFSA), 2(4), 76-92.

Kabir, G., \& Hasin, M. A. A. 2011. "Comparative analysis of AHP and fuzzy AHP models for multicriteria inventory classification." International Journal of Fuzzy Logic Systems, 1(1), 1-16.

Kabir, G., \& Sumi, R. S. 2014. "Power substation location selection using fuzzy analytic hierarchy process and PROMETHEE: A case study from Bangladesh.” Energy, 72, 717-730.

Kubler, S., Robert, J., Derigent, W., Voisin, A., \& Le Traon, Y. 2016. "A state-of the-art survey \& testbed of fuzzy AHP (FAHP) applications.” Expert Systems with Applications, 65, 398-422.

Kutlu AC, Ekmekçioglu M. 2012. "Fuzzy failure modes and effects analysis by using fuzzy TOPSIS-based fuzzy AHP." Expert Systems with Applications ;39(1): $61 \mathrm{e} 7$.

Kutlu, A. C., \& Ekmekçioğlu, M. 2012. "Fuzzy failure modes and effects analysis by using fuzzy TOPSIS-based fuzzy AHP." Expert Systems with Applications, 39(1), 61-67.

Kwong, C. K., \& Bai, H. 2003. "Determining the importance weights for the customer requirements in QFD using a fuzzy AHP with an extent analysis approach.” Iie Transactions, 35(7), 619-626.

Lin, C. T., \& Hsu, P. F. 2003. "Selection of internet advertising networks using an analytic hierarchy process and grey relational analysis." International journal of information and management sciences, 14(2), 1-16.

Liou, T. S., \& Wang, M. J. J. 1992. "Ranking fuzzy numbers with integral value.” Fuzzy sets and systems, 50(3), $247-$ 255.

Mangla, S. K., Kumar, P., \& Barua, M. K. 2015. "Risk analysis in green supply chain using fuzzy AHP approach: A case study." Resources, Conservation and Recycling, 104, 375-390.

Meydan, C., Yıldırım, B. F., \& Senger, Ö. 2016. “BİST’te işlem gören gıda işletmelerinin finansal performanslarının gri ilişkisel analiz yöntemi kullanılarak değerlendirilmesi.” Muhasebe ve Finansman Dergisi, (69), 147-171. 
Noorul Haq, A., \& Kannan, G. 2006. "An integrated approach for selecting a vendor using grey relational analysis.” International Journal of Information Technology \& Decision Making, 5(02), 277-295.

Organ, A., \& Yalçin, E. 2017. “An Integrated Approach Based on Fuzzy Ahp and Grey Relational Analysis for Heating Source Selection.” European Scientific Journal, ESJ, 13(12).

Özcan, T., Çelebi, N., \& Esnaf, Ş. 2011. "Comparative analysis of multi-criteria decision making methodologies and implementation of a warehouse location selection problem.” Expert Systems with Applications, 38(8), 97739779.

Ozdemir, Y., \& Basligil, H. 2016. "Aircraft selection using fuzzy ANP and the generalized choquet integral method: The Turkish airlines case.” Journal of Intelligent \& Fuzzy Systems, 31(1), 589-600.

Ozdemir, Y., Basligil, H., \& Karaca, M. 2011. "Aircraft selection using analytic network process: a case for Turkish airlines." In Proceedings of the World Congress on Engineering (WCE) (Vol. 8, pp. 9-13).

Özdemir, A. İ., \& Deste, M. 2009. "Gri ilişkisel analiz ile çok kriterli tedarikçi seçimi: Otomotiv sektöründe bir uygulama." Istanbul University Journal of the School of Business Administration, 38(2).

Özen Ö. D. Y., \& Koçak A. 2017. "Bulanık Analitik Hiyerarşi ve Bulanık Dematel Yöntemleri Kullanılarak Kurumsal Kaynak Planlaması Yazılım Seçimi ve Değerlendirilmesi.” Yönetim ve Ekonomi, 24 (3),927-957.

Pitchipoo, P., Venkumar, P., \& Rajakarunakaran, S. 2013. "Fuzzy hybrid decision model for supplier evaluation and selection." International Journal of Production Research, 51(13), 3903-3919.

Saaty, T. L., 1994. "How to make a decision: the analytic hierarchy process." Interfaces, 24(6), 19-43.

Samvedi, A., Jain, V., \& Chan, F. T. 2012. "An integrated approach for machine tool selection using fuzzy analytical hierarchy process and grey relational analysis." International Journal of Production Research, 50(12), 32113221.

Senger, Ö., \& Albayrak, Ö. K. 2016. "Gri İlişki Analizi Yöntemi İle Personel Değerlendirme Üzerine Bir Çalişma." International Journal of Economic \& Administrative Studies, (17).

Singh, R. K., Chaudhary, N., \& Saxena, N. 2018. "Selection of warehouse location for a global supply chain: A case study." IIMB management review, 30(4), 343-356.

Srdjevic, B., \& Medeiros, Y. D. P. 2008. "Fuzzy AHP assessment of water management plans." Water Resources Management, 22(7), 877-894.

Srichetta, P., and Thurachon, W., 2012. "Applying fuzzy analytic hierarchy process to evaluate and select product of notebook computers." International Journal of Modeling and Optimization, vol.2, no.2, pp.168.

Şahin, B., \& Yazır, D. 2019. "Uzmanlık katsayılarının belirlenmesinde kullanılan farklı yaklaşımların geliştirilmiş bulanık analitik hiyerarşi süreci metodu üzerindeki etkilerinin analizi." Journal of the Faculty of Engineering \& Architecture of Gazi University, 34(1).

Şen, C. G., \& Çınar, G. 2010. "Evaluation and pre-allocation of operators with multiple skills: A combined fuzzy AHP and max-min approach.” Expert Systems with Applications, 37(3), 2043-2053.

Tsai, C. H., Chang, C. L., \& Chen, L. 2003. "Applying grey relational analysis to the vendor evaluation model." International Journal of The Computer, The Internet and Management, 11(3), 45-53.

Ulutaş, A., Özkan, A. M., \& Tağraf, H. 2018. "Bulanık Analitik Hiyerarşi Süreci Ve Bulanik Gri İlişkisel Analizi Yöntemleri Kullanilarak Personel Seçimi Yapilması.” Electronic Journal of Social Sciences, 17(65).

Vahidnia, M. H., Alesheikh, A. A., \& Alimohammadi, A. 2009. "Hospital site selection using fuzzy AHP and its derivatives." Journal of environmental management, 90(10), 3048-3056.

Van Laarhoven, P. J., \& Pedrycz, W. 1983. “A fuzzy extension of Saaty's priority theory.” Fuzzy sets and Systems, 11(13), 229-241.

Wang, T. C., \& Chang, T. H. 2007. "Application of TOPSIS in evaluating initial training aircraft under a fuzzy environment." Expert Systems with Applications, 33(4), 870-880.

Wang, Y. M., Luo, Y., \& Hua, Z. 2008. "On the extent analysis method for fuzzy AHP and its applications.” European journal of operational research, 186(2), 735-747.

Yang, C. C., \& Chen, B. S. 2006. "Supplier selection using combined analytical hierarchy process and grey relational analysis." Journal of Manufacturing Technology Management, 17(7), 926-941.

Yeh, C. H., \& Chang, Y. H. 2009. "Modeling subjective evaluation for fuzzy group multicriteria decision making." European Journal of Operational Research, 194(2), 464-473.

Yin, Z. H., \& Lu, Q. 2009, April. "The grey comprehensive evaluation model of a third-party reverse ligistics provider selection.” In Artificial Intelligence, 2009. JCAI'09. International Joint Conference on (pp. 497-500). IEEE.

Zadeh, L.A., 1965. Fuzzy Sets, Information and Control, vol. 8, pp. 338-353. 